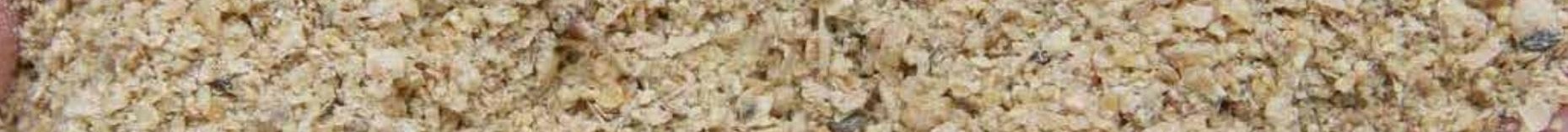

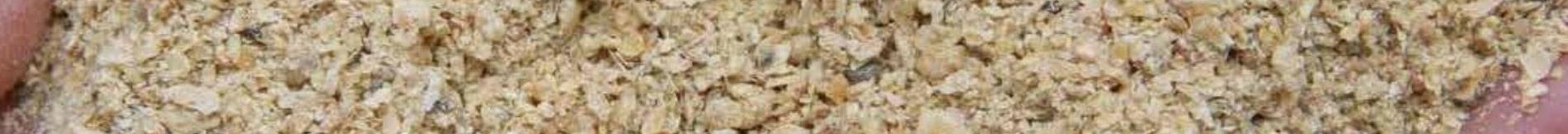
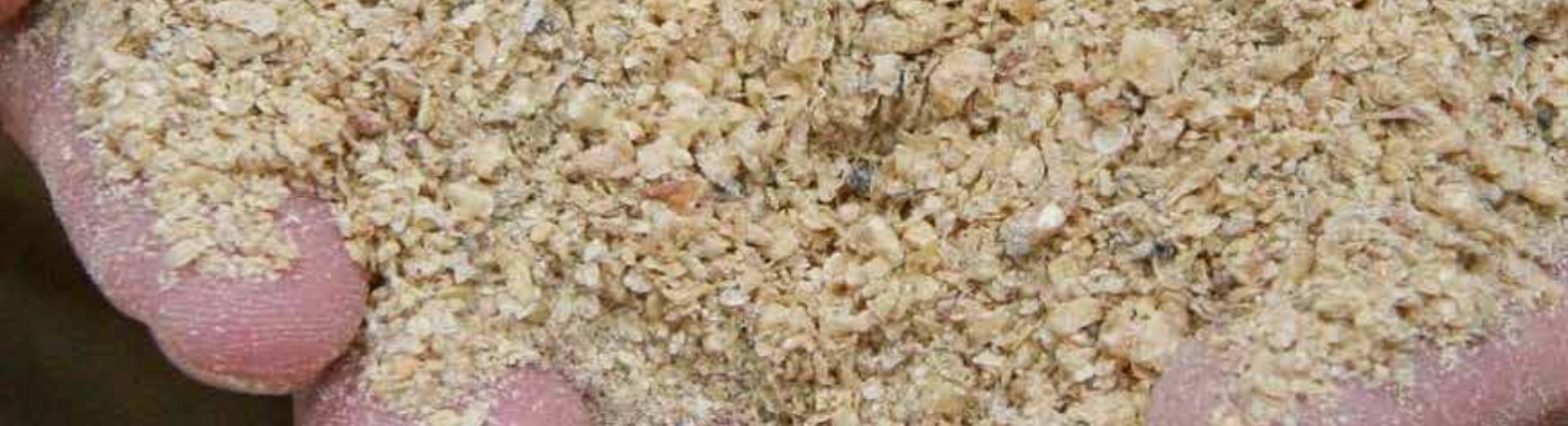

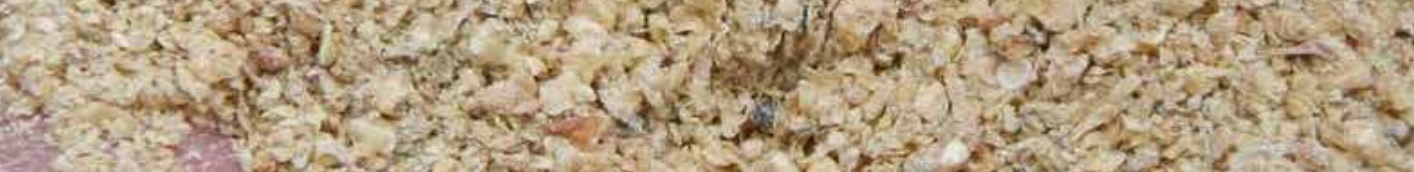
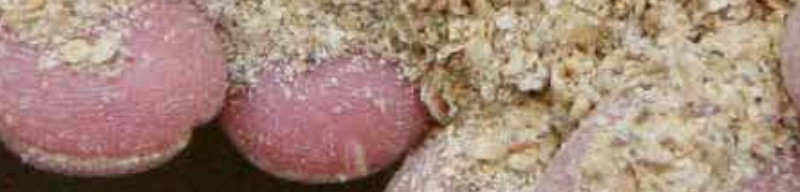

\title{
Economische effecten sluiting voermestkringloop
}

Huib Silvis, Peter van Horne, Roel Jongeneel, Ana Gonzalez Martinez, David Verhoog en Allard Jellema 



\section{Economische effecten sluiting voermestkringloop}

Huib Silvis, Peter van Horne, Roel Jongeneel, Ana Gonzalez Martinez, David Verhoog en Allard Jellema

Dit onderzoek is uitgevoerd door Wageningen Economic Research en gesubsidieerd door het ministerie van Landbouw, Natuur en Voedselkwaliteit, in het kader van de PPS Landbouw, water, voedsel, thema A3 Hergebruik zij- en reststromen (projectnummer WR-PPS AF18155)

Wageningen Economic Research

Wageningen, april 2021

RAPPORT

2021-023

ISBN 978-94-6395-774-8 
Silvis, H.J., P.L.M. van Horne, R.A. Jongeneel, A.R. Gonzalez Martinez, A.D. Verhoog en A. Jellema, 2021. Economische effecten sluiting voermestkringloop. Wageningen, Wageningen Economic Research, Rapport 2021-023. 50 blz.; 5 fig.; 21 tab.; 23 ref.

Aanpassing van het Nederlandse veevoer aan kringloopeisen ('Geen soja' in mengvoer of 'Alleen gebruik van Europese grondstoffen') leidt bij constante grondstofprijzen tot prijsstijgingen van krachtvoer. Afhankelijk van het scenario en de voersoort variëren die van $0 \%$ tot $14 \%$. Als Nederland meer grondstoffen uit Europa gaat betrekken, worden extra prijsstijgingen verwacht voor oliezaadschroot en overige eiwithoudende grondstoffen. Door de grote importafhankelijkheid van eiwitrijke grondstoffen is het intensieve veehouderijcomplex gevoeliger voor prijsstijgingen dan het grondgebonden veehouderijcomplex.

Trefwoorden: mengvoer, soja, scenario's, kringlooplandbouw

Adapting feed in the Netherlands to specific requirements of the feed cycle ('No soy' in compound feed or 'Use only European feed commodities') will lead to price increases in feed concentrates at constant feed commodity prices. Depending on the scenario and type of feed, these price increases will vary from $0 \%$ to $14 \%$. If the Netherlands starts to source more feed commodities from Europe, additional price increases are expected for oilseed meal and other protein raw materials. Due to the high import dependency of protein-rich feed commodities, the intensive livestock complex is more sensitive to price increases than the land-based livestock complex.

Keywords: compound feed, soybean, scenarios, circular agriculture

Dit rapport is gratis te downloaden op https://doi.org/10.18174/544953 of op www. wur. nl/economicresearch (onder Wageningen Economic Research publicaties).

(C) 2021 Wageningen Economic Research

Postbus 29703, 2502 LS Den Haag, T 07033583 30, E communications.ssg@wur.nl, www.wur. nl/economic-research. Wageningen Economic Research is onderdeel van Wageningen University \& Research.

\section{(cc) BY-NC}

Dit werk valt onder een Creative Commons Naamsvermelding-Niet Commercieel 4.0 Internationaallicentie.

(c) Wageningen Economic Research, onderdeel van Stichting Wageningen Research, 2021 De gebruiker mag het werk kopiëren, verspreiden en doorgeven en afgeleide werken maken. Materiaal van derden waarvan in het werk gebruik is gemaakt en waarop intellectuele eigendomsrechten berusten, mogen niet zonder voorafgaande toestemming van derden gebruikt worden. De gebruiker dient bij het werk de door de maker of de licentiegever aangegeven naam te vermelden, maar niet zodanig dat de indruk gewekt wordt dat zij daarmee instemmen met het werk van de gebruiker of het gebruik van het werk. De gebruiker mag het werk niet voor commerciële doeleinden gebruiken.

Wageningen Economic Research aanvaardt geen aansprakelijkheid voor eventuele schade voortvloeiend uit het gebruik van de resultaten van dit onderzoek of de toepassing van de adviezen.

Wageningen Economic Research is ISO 9001:2015 gecertificeerd.

Wageningen Economic Research Rapport 2021-023 | Projectcode 2282200515

Foto omslag: Shutterstock 


\section{Erratum bij Rapport 2021-023}

26 mei 2021

Bijlage 2 van het rapport bevat een eiwitbalans van Nederland naar het voorbeeld van de EUeiwitbalans in bijlage 1 . Bij nader inzien blijkt de geproduceerde hoeveelheid eiwit via grasland in de Nederlandse balans sterk onderschat te zijn. In plaats van 13,83 miljoen ton moet het 65,3 miljoen ton zijn. Als gevolg hiervan stijgt het aandeel ruwvoer op de balans van $14,28 \%$ naar 35,9\%. De correctie heeft ook gevolgen voor figuur 1.1 in de hoofdtekst, waarin de aandelen van het verbruik van diverse eiwitbronnen in de EU en Nederland worden getoond. In deze versie is zowel figuur 1.1 als tabel B2.1 gecorrigeerd. De correctie heeft verder geen gevolgen voor de berekeningen en uitkomsten in dit rapport. 



\section{Inhoud}

Erratum bij Rapport 2021-023 3

Woord vooraf 7

Samenvatting $\quad 8$

S.1 Belangrijkste uitkomsten 8

S.2 Overige uitkomsten 8

S.3 Methode 9

$\begin{array}{ll}\text { Summary } & 10\end{array}$

S.1 Main results 10

$\begin{array}{lll}\text { S.2 Other outcomes } & 10\end{array}$

S.3 Method 11

1

$\begin{array}{ll}\text { Inleiding } & 12\end{array}$

$1.1 \quad$ Probleemstelling 12

1.2 Economische betekenis van het veehouderijcomplex 12

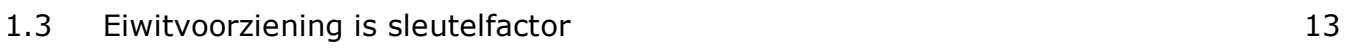

$\begin{array}{lll}2 & \text { Methodiek } & 17\end{array}$

$\begin{array}{lll}2.1 & \text { Analyse van scenario's } & 17\end{array}$

$\begin{array}{lll}2.2 & \text { Marktanalyse en modelgebruik } & 17\end{array}$

$\begin{array}{lll}2.3 & \text { Economie van kringloopsluiting op verschillende schaalniveaus } & 19\end{array}$

$3 \quad$ Referentiescenario: kleine daling veestapel in Nederland 21

$\begin{array}{lll}3.1 & \text { Inleiding } & 21\end{array}$

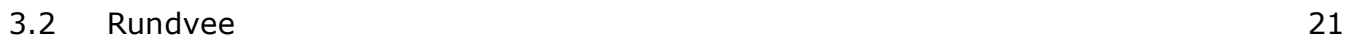

$\begin{array}{lll}3.3 & \text { Varkens } & 23\end{array}$

3.4 Pluimvee 23

$\begin{array}{lll}3.5 & \text { Veevoer } & 23\end{array}$

$4 \quad$ Alleen Nederlands veevoer: sterke reductie veestapel 25

4.1 Inleiding 25

4.2 Enkele uitkomsten uit eerder onderzoek 25

$\begin{array}{lll}4.3 & \text { Rundvee } & 27\end{array}$

$\begin{array}{lll}4.4 & \text { Varkens } & 27\end{array}$

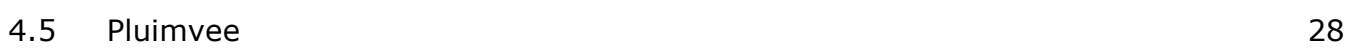

$\begin{array}{lll}4.6 & \text { Conclusie } & 28\end{array}$

$5 \quad$ Alleen Europees veevoer: hogere voerkosten 29

5.1 Inleiding 29

5.2 Rundvee 30

5.3 Varkens 32

5.4 Pluimvee 33

$\begin{array}{lll}5.5 & \text { Alternatieve eiwitbronnen } & 35\end{array}$

$\begin{array}{lll}5.6 & \text { Discussie en conclusies } & 36\end{array}$ 
$\begin{array}{lll}6.1 & \text { Inleiding } & 38\end{array}$

6.2 Scenario 'Alleen Nederland beperkt zich tot EU-veevoer' 38

6.3 Scenario 'EU-27 beperkt zich tot EU-27 veevoer' 39

6.4 Scenario 'Nederland en Duitsland beperken zich tot EU-veevoer' 40

6.5 Scenario 'Veevoer uit Oekraïne is toegestaan' 41

$\begin{array}{lll}6.6 & \text { Reflectie } & 41\end{array}$

$\begin{array}{llr}7 & \text { Slotbeschouwingen } & 43\end{array}$

$\begin{array}{ll}\text { Literatuur en websites } & 46\end{array}$

$\begin{array}{lll}\text { Bijlage } 1 & \text { Eiwitbalans EU } & 48\end{array}$

$\begin{array}{lll}\text { Bijlage } 2 & \text { Eiwitbalans Nederland } & 49\end{array}$ 


\section{Woord vooraf}

Binnen de PPS Kringlooptoets 2.0 Europese grondstoffen zijn verschillende scenario's van kringloopsluiting doorgerekend op milieukundige effecten. Sluiting van voermestkringlopen kan echter ook aanzienlijke economische gevolgen hebben voor het Nederlandse agrocomplex. Deze gevolgen zijn in de Kringlooptoets 2.0 niet uitgewerkt.

Dit project is een aanvulling op de PPS Kringlooptoets 2.0 en bedoeld om deze lacune op te vullen. Het verkent de economische effecten van in geografische schaal uiteenlopende scenario's. Ook wordt ingegaan op mogelijke belemmeringen in regelgeving en de in te zetten beleidsinstrumenten.

De beoogde impact van het project is dat beleidsmakers en bestuurders extra inzicht krijgen in de gevolgen van de eventuele sluiting van voermestkringlopen. Daarmee kunnen beter onderbouwde discussies gevoerd worden over de wenselijkheid en haalbaarheid van maatregelen.

Voor de gevolgen van kringloopmaatregelen op de samenstellingen en prijzen van veevoeders is een beroep gedaan op Schothorst Feed Research.

Het onderzoek is als onderdeel van het Maatschappelijk Innovatie Programma (MIP) gefinancierd vanuit de PPS Landbouw, Water en Voedsel, A3 Hergebruik zij- en reststromen. Projectnummer: WR-PPS AF18155.

De begeleidingscommissie werd geleid door Frank Gort (Nevedi). Andere leden van de commissie waren: Jan de Wilt (LNV), Eddy Esselink (MVO), Matthé Vermeulen (Comité van Graanhandelaren) en Theo Duteweerd (POV). De onderzoekers danken de begeleidingscommissie voor de constructieve samenwerking.

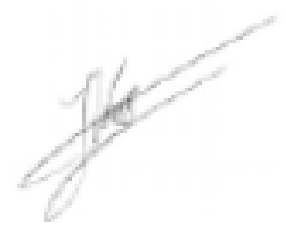

Prof.dr.ir. J.G.A.J. (Jack) van der Vorst Algemeen Directeur Social Sciences Group (SSG) Wageningen University \& Research

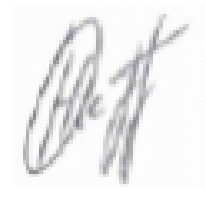

Ir. O. (Olaf) Hietbrink

Business Unit Manager Wageningen Economic Research Wageningen University \& Research 


\section{Samenvatting}

\section{S.1 Belangrijkste uitkomsten}

Deze studie onderzoekt de economische effecten van verschillende scenario's voor het sluiten van de voermestkringloop in Nederland. Een eerste variant gaat uit van een zeer nauwe sluiting van kringlopen: alleen Nederlands veevoer. Tegenover dit Nederland-autarkie-scenario worden enkele scenario's van Europese sluiting van voermestkringlopen gepresenteerd.

Het scenario waarbij voor de Nederlandse veehouderij alleen Nederlands veevoer beschikbaar is, leidt tot een extreme krimp van de veehouderijsectoren, variërend van 30\% (melkvee) tot 90\% (kippen).

Aanpassing van het Nederlandse veevoer aan kringloopeisen ('Geen soja' in mengvoer of 'Alleen gebruik van Europese grondstoffen') leidt bij constante grondstofprijzen tot prijsstijgingen van krachtvoer. Afhankelijk van het scenario en de voersoort variëren die van $0 \%$ tot $14 \%$.

Als Nederland meer grondstoffen uit Europa gaat betrekken, worden extra prijsstijgingen verwacht voor oliezaadschroot (raapzaad en zonnebloem) en overige eiwithoudende gewassen.

Relatief kleine prijsstijgingen kunnen een forse stijging van de voerkosten betekenen. Als de veehouder bij het gebruiken van 'circulair veevoer' geen hogere opbrengstprijs krijgt voor de producten (melk, vlees of eieren), staat het inkomen meteen onder druk.

De eventuele krimp en kostenverhogingen in de primaire sectoren werken door in de andere schakels van het veehouderijcomplex. Door de grote importafhankelijkheid van eiwitrijke grondstoffen is het intensieve veehouderijcomplex gevoeliger dan het grondgebonden veehouderijcomplex.

Als alle EU-27 lidstaten zich zouden beperken tot EU-veevoer lopen de krachtvoerprijzen fors op. Hierdoor verandert ook de concurrentiepositie van de dierlijke sectoren in de EU ten opzichte van die buiten de EU. Dat kan tot grote importen van dierlijke producten (zuivel, vlees, eieren) leiden, zeker als de EU geen compenserende maatregelen zou nemen om een gelijk speelveld te realiseren. Gebeurt dat niet, dan hebben bedrijven in de EU niet of nauwelijks de mogelijkheid om de (extra) kosten door te berekenen aan de eindgebruiker.

Gegeven dat de EU een tekortgebied is voor plantaardig eiwit, zal import van plantaardig eiwit nodig blijven om min of meer zelfvoorzienend te kunnen blijven met betrekking tot dierlijke producten (zuivel, vlees en eieren). De EU-afhankelijkheid van plantaardig eiwit bestaat al decennia en is niet afhankelijk van consumptietrends. Het is onwaarschijnlijk dat de lidstaten een kringloopidee zullen gaan omarmen waarbij de import van soja wordt uitgesloten. Dit zou ook in strijd zijn met de afspraken in het verband van de Wereldhandelsorganisatie.

\section{S.2 Overige uitkomsten}

In de huidige situatie is het vervangen van grote hoeveelheden Amerikaanse soja door EU-soja geen reële mogelijkheid door het zeer beperkte aanbod van EU-soja. Het is ook niet de verwachting dat op korte of middellange termijn grote hoeveelheden soja geteeld zullen gaan worden in Europa.

In steeds meer landen worden bedrijfsmatig insecten gekweekt. Op dit moment zijn er juridische en prijstechnische belemmeringen om insecteneiwit te gebruiken in diervoer. 
Het gebruik van diermeel biedt wel perspectief op korte en middellange termijn. Vooral diermeel van varkens gebruikt in vleeskuikenvoer geeft een hoogwaardig voer voor een lagere prijs. Vooralsnog is het gebruik van diermeel echter verboden.

\section{S.3 Methode}

Dit rapport verkent de economische gevolgen van het sluiten van de voermestkringloop. Naast het referentiescenario worden uiteenlopende varianten onderscheiden: van een scenario waarbij de omvang van de Nederlandse veehouderij gebaseerd is op de omvang van de nationale voederproductie tot een scenario waarbij de hele EU afziet van veevoerimport uit derde landen.

De scenario's met Europese grondstoffen zijn op twee manieren geanalyseerd. De eerste orde effecten voor de samenstelling en prijzen van het veevoer zijn bepaald in samenwerking met Schothorst Feed Research, waarbij is uitgegaan van constante marktprijzen van de grondstoffen, gelijkblijvende omvang van de veestapel en gelijkblijvende nutritionele voorwaarden. De belangrijkste soorten voer voor melkvee, varkens en pluimvee zijn geanalyseerd. In tweede instantie is een marktmodel gebruikt, om per scenario een indicatie te kunnen geven van de onvermijdelijke prijsgevolgen. 


\section{Summary}

\section{S.1 Main results}

This study examines the economic effects of different scenarios for closing the feed cycle in the Netherlands. A first scenario assumes a very narrow closure of cycles: only Dutch feed for Dutch livestock. Next to this Netherlands-autarky scenario, some scenarios of European closing of feed cycles are presented.

The scenario 'Dutch feed only' is accompanied by an extreme contraction of the livestock sectors, ranging from $30 \%$ (dairy cattle) to $90 \%$ (chickens).

Adapting Dutch cattle feed to circular requirements ('no soy' in compound feed or 'only use of European raw materials') leads, at constant raw material prices, to price increases for concentrated feed. Depending on the scenario and the type of feed, these will vary from $0 \%$ to $14 \%$.

If the Netherlands starts to source more raw materials from Europe, additional price increases are expected for oilseed meal (rapeseed and sunflower) and other protein crops.

Relatively small price increases can mean a substantial increase in feed costs. If the farmer does not receive a higher yield price for the products (milk, meat or eggs) when using 'circular feed', income is immediately under pressure.

Any contraction and cost increases in the primary sectors will affect the other links in the livestock complex. Due to the high import dependency of protein-rich raw materials, the intensive livestock complex is more sensitive than the land-based livestock complex.

In the scenario 'All EU-27 member states limit themselves to EU feed', feed prices rise sharply. This also changes the competitive position of the animal sectors in the EU compared to those outside the EU. This could lead to large imports of animal products (dairy, meat, eggs), especially if the EU does not take compensatory measures to create a level playing field. If that does not happen, companies in the EU will have little or no opportunity to pass on the (additional) costs to the end user.

Given that the EU is a deficit area for vegetable protein, imports of vegetable protein will continue to be necessary to remain more or less self-sufficient with respect to animal products (dairy, meat and eggs). The dependency is hardly influenced by consumption trends. It therefore seems unlikely that member states will embrace a circular idea that excludes soybean imports.. It would also be contrary to the commitments made in the context of the World Trade Organization.

\section{S.2 Other outcomes}

In the current situation, replacing large quantities of US soy with EU soy is not a real possibility due to the very limited supply of EU soy. It is also not expected that large quantities of soy will be grown in Europe in the short or medium term.

In an increasing number of countries, insects are farmed on a commercial basis. At present, there are legal and price restrictions on the use of insect protein in animal feed.

The use of meat and bone meal does offer prospects in the short and medium term. In particular, animal meal from pigs used in broiler feed provides a high quality feed at a lower price. For the time being, however, the use of animal meal is prohibited. 


\section{S.3 Method}

This report explores the economic consequences of closing the feed cycle. In addition to the reference scenario, several variants are distinguished: from a scenario in which the size of the Dutch livestock sector is based on the size of the national feed production to a scenario in which the entire EU renounces feed imports from third countries.

The scenarios with European feedstocks were analysed in two ways. The first-order effects for feed composition and prices were determined in cooperation with Schothorst Feed Research, assuming constant market prices of raw materials, constant livestock size and constant nutritional condition. The main types of feed for dairy cattle, pigs and poultry were analysed. Secondarily, a market model was used, in order to give an indication of the unavoidable price consequences per scenario. 


\section{$1 \quad$ Inleiding}

\subsection{Probleemstelling}

Recent zijn er veel visies en bijdragen verschenen die pleiten voor een meer circulair voedselsysteem, door het sluiten van kringlopen en het gebruiken van meer regionale grondstoffen in (kracht)voeders (bij voorbeeld: Visie LNV: waardevol en verbonden, Advies Commissie Grondgebondenheid, Uitvoeringsprogramma Circulaire Economie).

Voermestkringlopen kunnen gesloten worden op mondiaal, Europees of nationaal niveau (zie bijvoorbeeld Berkum et al., 2019). Binnen die geografische schalen zijn diverse maatregelen denkbaar om kringlopen meer gesloten te krijgen. Zo kan worden gedacht aan het inzetten van nieuwe eiwitbronnen als veevoer (bijvoorbeeld zeewier en insecten), het verwerken van dierlijke mest tot waardevolle meststoffen voor toepassing in andere landen of sectoren, het hergebruik van reststromen uit de levensmiddelenindustrie, de toelating van diermeel als veevoer, het vervangen van krachtvoergrondstoffen door EU-grondstoffen (EU-eiwitplan) en/of lokale plaatsing van mest en productie van ruwvoer.

Dit project verkent de economische gevolgen van het sluiten van voer-mestkringlopen op verschillende schaalniveaus. De concrete invulling van de gewenste kringlooplandbouw, en specifiek het schaalniveau waarop voer-mestkringlopen gesloten worden, kan grote gevolgen hebben voor het Nederlandse agrocomplex.

\subsection{Economische betekenis van het veehouderijcomplex}

Het agrocomplex bestaat uit het geheel van economische activiteiten in en rond de primaire plantaardige en dierlijke productie. Bij de dierlijke productie kan onderscheid gemaakt worden tussen het grondgebonden veehouderijcomplex en het intensieve veehouderijcomplex. Het intensieve veehouderijcomplex bestaat uit de deelcomplexen van varkens, pluimvee en vleeskalveren (tabel 1.1).

Het grondgebonden veehouderijcomplex bestaat uit melkveebedrijven, overige graasdierbedrijven (schapen, paarden en geiten), slachterijen, zuivelindustrie, en de toelevering en distributie voor het deel dat deze sectoren aan de primaire grondgebonden veehouderijbedrijven of de verwerkende industrieën leveren. Toeleveranciers zijn de loonwerkbedrijven, zakelijke dienstverleners, kunstmestindustrie en veevoederindustrie.

De toegevoegde waarde van het melkveecomplex bedroeg circa 8,5 mld. euro in 2018 . Het aandeel van de primaire sector in 2018 was $21 \%$, vergelijkbaar met dat in de periode 2010-2016. In 2017 lag dit aandeel hoger (bijna 25\%), wat vooral te danken was aan de hoge melkprijs in 2017 met bijgevolg hoge inkomens voor melkveehouders. De toelevering is met een aandeel van $43 \%$ de grootste schakel qua werkgelegenheid. De primaire bedrijven namen $36 \%$ van de werkgelegenheid van het melkveecomplex voor hun rekening. 
Tabel 1.1 Economische betekenis van veehouderijcomplexen in Nederland, 2018

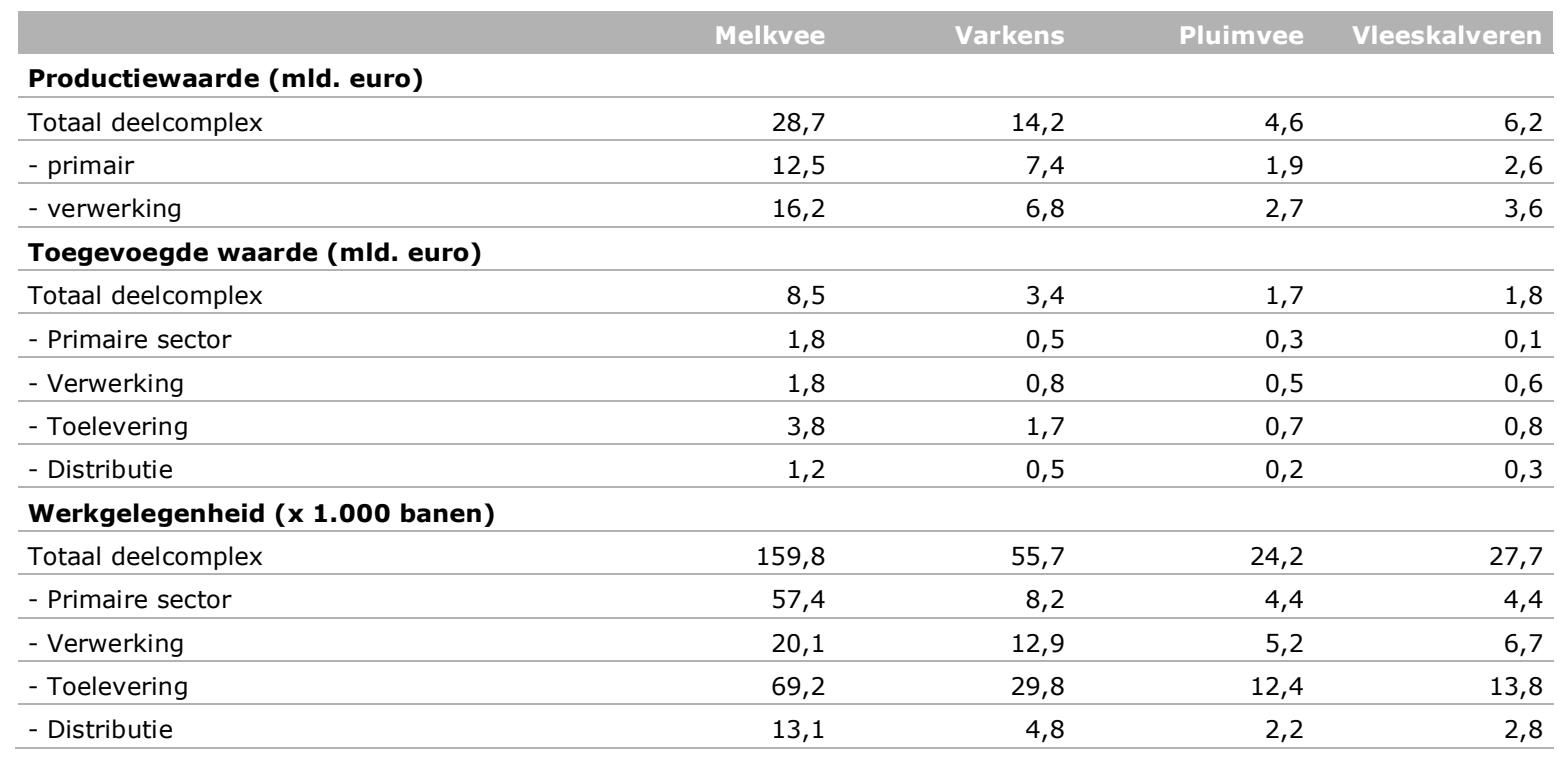

Bron: Wageningen Economic Research.

Het intensieve veehouderijcomplex omvat de varkens-, pluimvee- en vleeskalverenhouderij en de aan deze sectoren verbonden slachterijen en vleesverwerkers. Daarnaast maken toeleveranciers (waaronder de veevoederindustrie) en distributiebedrijven deel uit van dit complex. De toegevoegde waarde van het intensieve veehouderijcomplex bedroeg circa 7 mld. euro in 2018, gelijk aan 2017. Het varkenscomplex is het grootste deelcomplex, zowel in termen van productiewaarde, toegevoegde waarde als werkgelegenheid (tabel 1.1). Het aandeel van de primaire sector in de toegevoegde waarde was in 2018 gedrukt door lage prijzen voor varkens. Dit kwam door een groter aanbod in de EU, in combinatie met moeizamere export naar China. In 2019 trokken de varkensprijzen overigens sterk aan door de productieproblemen in China vanwege het uitbreken van Afrikaanse varkenspest.

\subsection{Eiwitvoorziening is sleutelfactor}

Bij de voederrantsoenen in de veehouderij draait het hoofdzakelijk om de energievoorziening en de eiwitvoorziening. In de context van de EU en het sluiten van kringlopen is de eiwitvoorziening de sleutelfactor. De reden hiervan is dat de EU al sinds haar ontstaan een belangrijk tekortgebied voor plantaardig eiwit is. Dit tekort wordt in belangrijke mate gedekt door importen van oliezaden (met name soja uit Noord- en Zuid-Amerika). Naar aanleiding hiervan moet eiwit de focus van de analyse zijn. De vraag vanuit de energie-kant lijkt minder beperkend omdat de EU in dat opzicht zelfs nettoexporterend is.

\section{EU-eiwitbalans}

De EU-eiwitbalans vormt het startpunt van de analyse (bijlage 1). De tabel laat zien dat ongeveer tweederde van de (ruw) eiwitvoorziening direct afkomstig is van in de EU geteelde gewassen (granen, oliezaden, peulvruchten) en ruwvoer (met name gras). Het overige deel is afkomstig van diverse industriële en bijproducten, waarbij geïmporteerd schroot van oliezaden (circa $24 \mathrm{mln}$. ton) een belangrijk aandeel heeft (26\%). Vanuit deze balans is het duidelijk dat een economische analyse van het sluiten van kringlopen op niveau van de EU de volgende variabelen moet meenemen:

- EU-productie van gewassen en ruwvoer;

- beschikbaarheid van industriële producten en bijproducten;

- omvang en samenstelling van de internationale handel.

Het eiwit wordt benut in de dierlijke productie, waarbij het wordt omgezet in eindproducten voor consumptie (zuivel, vlees, eieren). De dierlijke productie van de EU in de uitgangssituatie is gebaseerd op de Medium Term EU Market Outlook (EC, 2020a) (tabel 1.2). Hierbij valt op dat circa twee derde van de totale vraag vanuit de melkveehouderij en rundvleesproductie komt. Rundvee en schapen zijn 
herkauwers, die een groot deel van hun eiwitbehoefte kunnen dekken vanuit ruwvoer. Varkens en pluimvee zijn hoofdzakelijk aangewezen op krachtvoeders. De totale vraag komt uit op 71,3 mln. ton ( $87 \%$ van totale beschikbaarheid, zie bijlage 1 ). De werkelijke vraag zal nog iets hoger liggen omdat enkele relatief onbelangrijke diercategorieën niet voldoende zijn meegenomen (zoals moederdieren, fokvee, jongvee dat voor reproductie/vervanging wordt ingezet) en er nog andere diercategorieën zijn zoals overig gevogelte (kalkoenen, eenden en dergelijke) en kweekvis.

Tabel 1.2 Schatting van verbruik ruw eiwit ( $\mathrm{m} / \mathrm{n}$. ton), afgeleid van de dierlijke productie in de EU, 2018

\begin{tabular}{lrrrrrrr} 
Sectoren & Melkvee & Rundviees & Varkensvlees & Pluimveevlees & Eieren & Schapen \\
Producten & 164,0 & 8,0 & 24,0 & 13,3 & 6,7 & 0,9 & 216,9 \\
\hline 'voederconversie' a) & 1,4 & 10,9 & 3,9 & 2,1 & 2,8 & 4,5 & 2,1 \\
\hline voer verbruik & 225,5 & 86,9 & 90,1 & 28,2 & 18,9 & 3,9 & 453,5 \\
\hline Eiwitgehalte & $17 \%$ & $12 \%$ & $16 \%$ & $16 \%$ & $16 \%$ & $15 \%$ & $15,7 \%$ \\
\hline verbruik ruw eiwit & 38,3 & 10,4 & 14,4 & 4,5 & 3,0 & 0,6 & 71,2 \\
\hline$\%$ aandelen & 53,8 & 14,6 & 20,2 & 6,3 & 4,3 & 0,8 & 100 \\
\hline
\end{tabular}

a) De berekende voederconversies zijn de resultante van het voerverbruik van de gehele keten gedeeld door de hoeveelheid eindproduct. Ze zijn hoger dan de gangbare voerderconversies omdat hier jongvee, opfok of ouderdieren impliciet ook worden toegerekend aan de sectoren. Bron: eigen berekeningen op basis van Eurostat, FEFAC en AGMEMOD-data.

De dierlijke productie dient hoofdzakelijk voor de EU-voedselvoorziening (zie tabel 1.3). Er is ook sprake van import en export, maar die heeft ten opzichte van de binnenlandse productie een bescheiden karakter. Grosso modo geldt dat de EU vooral veevoedergrondstoffen importeert om als EU zelfvoorzienend te zijn met dierlijke producten.

Het risico bestaat dat wanneer veevoerkringlopen worden gesloten (met beperking van EU- of lidstaatimporten) er als 'uitweg' meer dierlijke producten zullen worden geïmporteerd. Voor het ene 'lek' dat wordt gedicht ontstaat zo mogelijk een 'nieuw lek'. Dit geeft aanleiding om aan een economische analyse nog een aantal extra voorwaarden te stellen:

- Dierlijke ketens moeten van veevoergrondstof tot eindproduct in beschouwing worden genomen.

- Het consumentengedrag als reactie op kringloop-sluitingsmaatregelen moet in beschouwing worden genomen, waarbij rekening moet worden gehouden met:

- de response van afnemers van dierlijke producten met betrekking tot prijsaanpassingen

- de eventuele 'uitwijk-route' naar import van dierlijke producten en de lekkage die dit creëert.

Tabel 1.3 Verbruik ( $\mathrm{m} / \mathrm{n}$. ton) van dierlijke producten in de EU, handel en zelfvoorzieningsgraad (2018)

\begin{tabular}{lrrrrrr} 
Sectoren & Melkvee & Rundvlees & Varkensvlees & Pluimveevlees & Eleren Schapen \\
EU-verbruik & 134,5 & 8,0 & 21,4 & 14,1 & 6,5 & 1,0 \\
\hline EU-productie & 164,0 & 8,0 & 24,0 & 13,3 & 6,7 & 0,9 \\
\hline Netto-import & $-29,5$ & 0,1 & $-2,6$ & $-0,1$ & 0,8 & 0,1 \\
\hline Aandeel van importen & $-0,18$ & 0,01 & 1,06 & $-0,03$ & 0,17 \\
\hline Zelfvoorzieningsgraad a) & 1,22 & 0,99 & 0,94 & 1,03 & 0,86 \\
\hline
\end{tabular}

a) De zelfvoorzieningsgraad is berekend als EU-productie gedeeld door EU-consumptie. De uitkomst kan afwijken van de zelfvoorzieningsgraad zoals die wordt berekend op basis van gedetailleerde gebruikstabellen.

Bron: eigen berekeningen op basis van Eurostat en AGMEMOD-data.

\section{Nederlandse eiwitbalans}

Voor de analyse van scenario's met betrekking tot het sluiten van kringlopen is het belangrijk om de positie van Nederland binnen de EU goed in beeld te hebben. Daarom is er, analoog aan die van de EU, ook een Nederlandse eiwitbalans gemaakt (bijlage 2). 
Figuur 1.1 geeft een vergelijking van de procentuele aandelen in het verbruik, gemeten in hoeveelheden eiwit van diverse eiwitbronnen in Nederland en de EU. Voor Nederland is het relatief grote aandeel van oliezaden als eiwitbron opvallend. Dit hangt samen met de relatief grote eiwitimportbehoefte van Nederland door de sterk ontwikkelde intensieve veehouderij en de gunstige infrastructuur voor de aanvoer van overzeese grondstoffen (havens). Wat verder opvalt is dat de rol van bijproducten in Nederland groter is dan in de EU als geheel. Daar staat tegenover dat het aandeel van ruwvoer lager is. Deze verhoudingsgetallen illustreren de intensiteit van de Nederlandse dierlijke productie, die sterk leunt op krachtvoer en minder op ruwvoer.

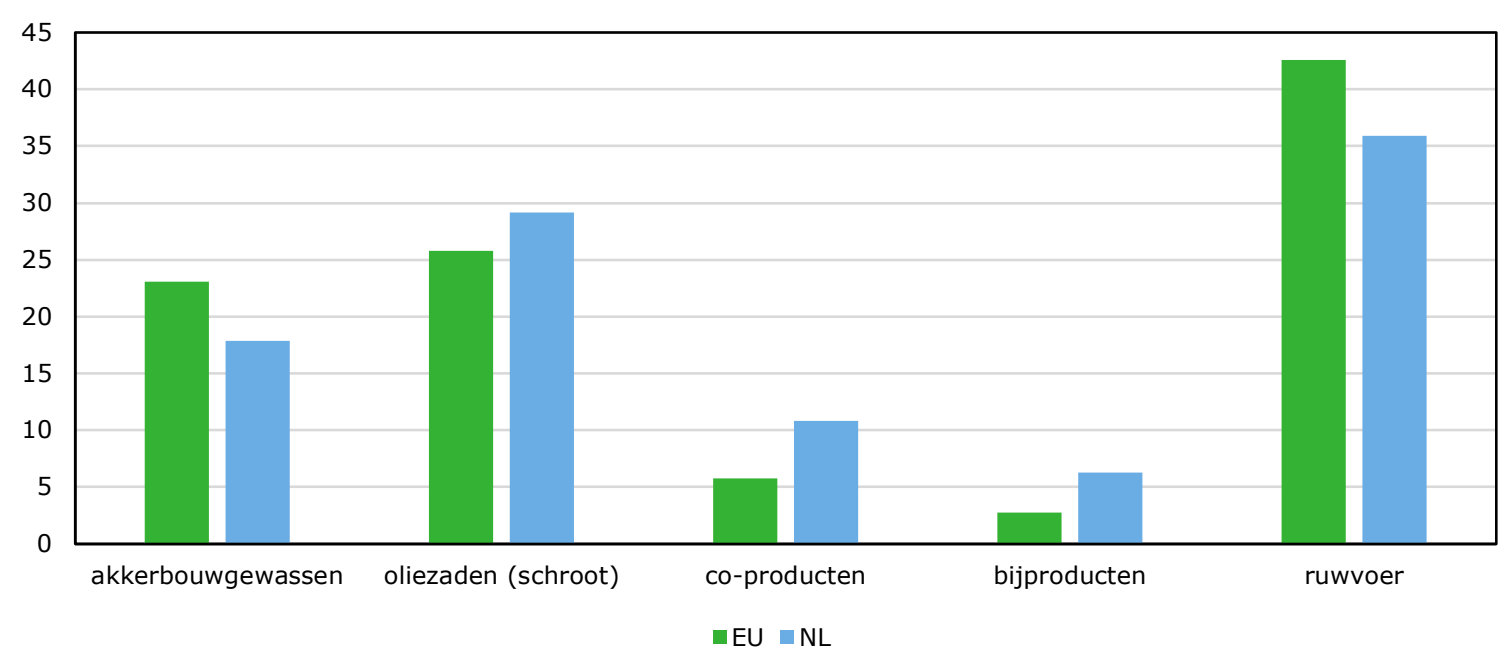

Figuur 1.1 Aandelen (\%) van verbruik van diverse eiwitbronnen in EU en NL gemeten in hoeveelheden eiwit

De herkomst van eiwitrijke diervoedergrondstoffen ( $>154 \mathrm{~g} / \mathrm{kg}$ ruw eiwit) in Nederland is onderzocht door Van Krimpen en Cormond (2019). Zij komen voor 2018 op een percentage van 47\% regionale grondstoffen (betreft in EU geteelde gewassen). Het aandeel van regionale eiwitgrondstoffen verschilt per sector: dit is het laagst (23\%) bij pluimveevlees (tabel 1.4 ).

Tabel 1.4 Hoeveelheid eiwit van eiwitrijke diervoedergrondstoffen ( $>154 \mathrm{~g} / \mathrm{kg}$ ruw eiwit) per diercategorie (kton) en de totale hoeveelheid eiwit in het Nederlands mengvoer (kton), onderverdeeld naar regionale (binnen EU geteeld) en niet-regionale (buiten EU geteeld) herkomst, 2018

\begin{tabular}{lrrr} 
& Regional & Niet-regionaal & \% regionaal \\
Melkvee & 232 & 258 & 47 \\
\hline Vleesvee & 93 & 27 & 78 \\
\hline Varkens & 182 & 213 & 46 \\
\hline Pluimveevlees & 59 & 195 & 23 \\
\hline Leghennen & 98 & 70 & 58 \\
\hline Overig & 20 & 14 & 60 \\
\hline Totaal & 685 & 772 & 47 \\
\hline
\end{tabular}

Bron: Van Krimpen en Cormond (2019).

Wanneer ook eiwitrijke vochtrijke bijproducten worden meegenomen, is het aandeel eiwit van regionale oorsprong $50 \%$ in 2018 . Als de herkomst van het eiwit uit alle mengvoergrondstoffen wordt genomen (inclusief deze met minder dan $154 \mathrm{~g} / \mathrm{kg}$ ruw eiwit zoals de granen) dan is 65\% van het eiwit in mengvoer van regionale herkomst. 
De totale hoeveelheid eiwit aangewend voor veevoer in Nederland bedraagt 4,85 mln. ton (dat is bijna $6 \%$ van het EU-totaal). Voor bijproducten en oliezaden kan het Nederlandse aandeel van de EU fors hoger zijn (rond de $20 \%$ ).

Uit de balansvergelijking kan worden afgeleid dat Nederland zijn grondstoffen in principe volledig uit in de EU geproduceerde grondstoffen zou kunnen betrekken. Ervan uitgaande dat het gebruik van bijproducten als kringloop-bestendig wordt gezien, zit de kwetsbaarheid van de Nederlandse eiwitvoorziening vooral bij het gebruik van niet-regionaal geproduceerde oliezaden (in het bijzonder soja). Bij het sluiten van kringlopen zal de vervanging van soja, dat nu vooral uit Noord- en Zuid Amerika wordt geïmporteerd, dan ook een grote rol spelen. 


\section{$2 \quad$ Methodiek}

\subsection{Analyse van scenario's}

Dit onderzoek verkent scenario's voor het sluiten van de voermestkringloop en berekent de economische effecten op sectorniveau en nationaal niveau. Om voldoende bandbreedte te hebben worden de volgende scenario's onderscheiden:

1. een referentiescenario dat uitgaat van ongewijzigd beleid;

2. een scenario dat uitgaat van een zeer nauwe sluiting van kringlopen: Nederland sluit de voermestkringloop op eigen grondgebied door de omvang van de veehouderij te reduceren tot deze in balans is met de nationale omvang van de voederproductie;

3. scenario's die kunnen worden gekarakteriseerd als Europese sluiting van kringlopen (Europees veevoer). Hierbij worden varianten bekeken, zoals:

- Alleen NL beperkt zich tot EU-veevoer

- NL en DLD beperken zich tot EU-veevoer

- Alle EU-27 lidstaten beperken zich tot EU-veevoer

- Veevoer uit Oekraïne is toegestaan.

\section{Ad 1.}

De uitwerking van het referentiescenario is gebaseerd op de EU-landbouwvooruitzichten (EU Agricultural Outlook). Deze vooruitzichten zijn een vooruitblik voor de belangrijkste landbouwmarkten in de EU tot 2030. Hierop aansluitend zijn projecties voor Nederland gemaakt. Zie hoofdstuk 3.

\section{Ad 2.}

Hoe ziet de Nederlandse veehouderij eruit als het vee uitsluitend gevoerd wordt met Nederlands voer? De beantwoording van deze vraag is in de eerste plaats gebaseerd op literatuuronderzoek. Om een scherper inzicht te geven in de directe effecten, zijn aanvullende berekeningen gemaakt met het programma Feedprint. Zie hoofdstuk 4.

\section{Ad 3.}

De manier waarop de voermestkringloop wordt gesloten heeft gevolgen voor de samenstellingen en prijzen van veevoeders. De eersteorde-effecten voor de samenstelling en prijzen van het veevoer van diverse varianten zijn bepaald door Schothorst Feed Research (SFR). Zie hoofdstuk 5.

De invulling van de scenario's heeft gevolgen voor de markten, bijvoorbeeld door schaarste en dus prijzen van eiwitrijkveevoer als de import wordt beperkt. Om die markteffecten in beeld te kunnen brengen, is een economisch model ontwikkeld. De achtergrond van dit model wordt hieronder toegelicht. Vervolgens wordt geschetst hoe het model de uitwerking van verschillende schaalniveaus van kringloopsluiting simuleert. De uitkomsten van de analyses zijn beschreven in hoofdstuk 6 .

\subsection{Marktanalyse en modelgebruik}

Economische modellen die de EU-voersector en die van de lidstaten goed afdekken zijn niet direct beschikbaar. De uitzondering is mogelijk het CAPRI-model van de Europese Commissie, maar daarvan is niet geheel duidelijk in hoeverre de bijproducten goed afgedekt worden. Die laatste zijn essentieel om mede in beschouwing te nemen, zowel gezien hun huidige belang (zie hoofdstuk 1), als vanwege kringlooplandbouw-overwegingen, waarin het gebruik van bijproducten juist als een waardevolle bijdrage van de landbouw aan circulariteit wordt gezien (De Boer en Van Ittersum, 2018). Er zijn wel economische modellen die belangrijke onderdelen van het EU voer-dier-consumentenvraagsysteem afdekken. Een voorbeeld daarvan is het AGMEMOD market outlook model (bevat gewasproductie, dierlijke productie en consumentenvraag zowel op geaggregeerd EU-niveau als op EU-lidstaatniveau). 
Bezien vanuit de probleemstelling moet het economische analysekader aan een aantal voorwaarden voldoen. Tegelijkertijd geldt dat een passend model dat aan alle voorwaarden voldoet niet voorhanden is. $\mathrm{Er}$ is daarom gekozen om een model-instrumentarium te ontwikkelen dat wel aan de gestelde voorwaarden voldoet. Daarbij is de zogenaamde equilibrium displacement-modellering (EDM) gevolgd (Harrington en Dubman, 2018). Deze EDM-techniek is geschikt om een passend model te construeren dat de essentiële trade-offs die ter discussie staan omvat, waarbij zoveel mogelijk gebruik wordt gemaakt van al bestaande informatie. Die informatie betreft in dit geval zowel de data (waaronder de eiwitbalansen en market outlook data) als informatie over consumenten- en producentengedrag zoals dat impliciet in andere modellen zit (of vanuit literatuurstudies bekend is).

In het kader van dit project is een relatief eenvoudig EDM-model gebruikt dat gevoed wordt met de informatie uit de besproken eiwitbalansen van de EU en Nederland (bijlagen 1 en 2). Daaruit kan via substractie de (impliciete) eiwitbalans van 'de rest van de EU' worden afgeleid. Op die manier kan een model worden geconstrueerd waarin de EU is opgesplitst in twee regio's, te weten Nederland en de rest van de EU. Daarnaast is er een regio 'de rest van de wereld'. Zowel Nederland als de EU onderhouden een relatie met de rest van de wereld en importeren eiwithoudende veevoergrondstoffen uit die regio. De data voor deze importen komen in principe ook uit de eerder gepresenteerde eiwitbalansen. Het EDM-model is gekalibreerd op de (gestileerde) eiwitbalansen als 'basisjaar' (onder de aanname van een genormaliseerde eiwitprijs).

De vraag-elasticiteiten naar eiwitrijk veevoer hangen samen met de structuur van de dierlijke sectoren en de 'afhankelijkheid' van eiwitrijke krachtvoeders. Voor zowel Nederland als de EU is die op -0,1 gesteld. De gebruikte elasticiteiten zijn afkomstig van een recente econometrische studie waarin deze elasticiteiten voor de EU econometrisch zijn geschat (Jongeneel en Gonzalez Martinez, 2020). De prijsinelastische vraag illustreert het gebrek aan alternatieve eiwitbronnen en de noodzaak om toegang tot krachtvoer te hebben, zeker voor de intensieve veehouderij. De aanbodelasticiteit van de binnenlandse productie van eiwitrijke veevoergrondstoffen voor Nederland en de EU is respectievelijk 0,1 en 0,2 (schatting ook gebaseerd op de eerder aangehaalde recente EU-studie). De excess aanbodelasticiteiten van eiwitrijke veevoergrondstoffen voor Nederland en de rest van de EU zijn respectievelijk 10 en 2,5 (expertschatting op basis van literatuur en een productie/gebruik aandelenweging). Dit betekent dat vraag van Nederland en de EU op de buitenlandse markt relatief weinig effect heeft op de wereldmarktprijs van veevoer (zie Pft in figuur 2.1). De vraag- en aanbodsfuncties hebben een zogenaamde constant elasticity-specificatie (het voordeel daarvan is dat de elasticiteiten tegelijk parameters zijn en dat gecurvde en asymptotische structuur ervoor zorgt dat een dergelijk model flinke schokken kan doorstaan en dan nog steeds verwacht gedrag laat zien).

EDM-modellen hebben voordelen (relatief eenvoudig in vergelijking tot echte partiële en algemeenevenwicht-modellen), maar ook nadelen. Het eerste nadeel is dat ze comparatief statisch zijn en dus moeilijk dynamische aanpassingsprocessen kunnen weergeven. Een tweede nadeel is dat er in vergelijking met bovengenoemde partiële en algemeen-evenwichtsmodellen ook een beperkt aantal markten worden meegenomen, die mogelijk het effect van een prijsstijging zouden kunnen dempen, bijvoorbeeld doordat een kostenstijging wordt gecompenseerd door een kostendaling elders of doordat de kostenstijging gedeeltelijk wordt doorberekend in de prijs van een product, zie ook hieronder. Een derde nadeel is dat ze eigenlijk alleen een goede benadering van de reacties en marktindicatoren geven, als er sprake is van relatief beperkte 'schokken' (beleidsingrepen) op het systeem. Als het oogmerk is om een gestileerde analyse te maken, is het doen van een comparatief-statische analyse geen probleem, mits zorgvuldig wordt gekeken naar de gedragsparameters (de elasticiteiten moeten betrekking hebben op de termijn waarin men de aanpassingen voorziet) (Jongeneel en Tonini, 2009 en Jongeneel et al., 2018). Het alleen kunnen analyseren van beperkte schokken is voor onze analyse wel een bezwaar, omdat het hanteren van kringloopprincipes, waarbij de (netto-)import volledig naar nul kan worden teruggebracht tot 'grote schokken' aanleiding zal geven. Wanneer de zogenaamde 'linearisering' (=benadering) die in EDM-modellen gebruikelijk is wordt losgelaten, kan een modelspecificatie worden verkregen waarin wel grote schokken kunnen worden geanalyseerd, al zijn dergelijke modellen niet langer algebraïsch op te lossen (er moeten numerieke oplossingsalgoritmen worden gebruikt) (Smit et al., 2017). Die laatste benadering is hier toegepast omdat het sluiten van kringlopen in modeltermen het analyseren van potentieel grote schokken impliceert. 
In het onderzoek is daarom gewerkt met een (niet-gelineariseerd) EDM-model (geschikt voor analyse van grotere schokken). Omdat het voorstelbaar is dat in het geval kringloop-restricties aan de landbouw worden opgelegd de landallocatie zich sterk zou kunnen aanpassen, is er een speciale voorziening getroffen die enerzijds flexibiliteit geeft (grotere aanpassingen toelaat dan onder standaardcondities plaatsvinden), terwijl tegelijkertijd wordt gegarandeerd dat de marktbalansen sluiten. De essentie van de modelopzet is in een vereenvoudigde vorm grafisch weergegeven (figuur 2.1). De drie onderscheiden landen/regio's (Nederland, de rest van de EU en de rest van de wereld) worden elk gekarakteriseerd door een eigen aanbod van en een eigen vraag (vanwege de dierlijke sectoren) naar eiwitrijk veevoer. Het gedrag daarachter is weergegeven via (stijgende) aanbodfuncties en (dalende) vraagfuncties. Het aanbod van eiwitrijke veevoerproducten die in Nederland worden geteeld, wordt weergegeven door $\mathrm{S}_{\mathrm{NL}}$, terwijl de vraag naar eiwitrijke producten door de diverse dierlijke sectoren is samengevat in $D_{\mathrm{NL}}$. Op eenzelfde manier is dit voor de rest van de EU het geval. De relatie met de rest van de wereld (zie rechterpanel) is weergegeven door de aanbodcurve van eiwitrijke grondstoffen van de rest van de wereld (hun exportfunctie ES $_{\text {Row) }}$ richting de EU-27, terwijl de vraag van de EU-27 wordt gerepresenteerd door de excess vraagcurve ED NL/RoEU die de geaggregeerde importvraag van zowel Nederland als de rest van de EU samenvat.

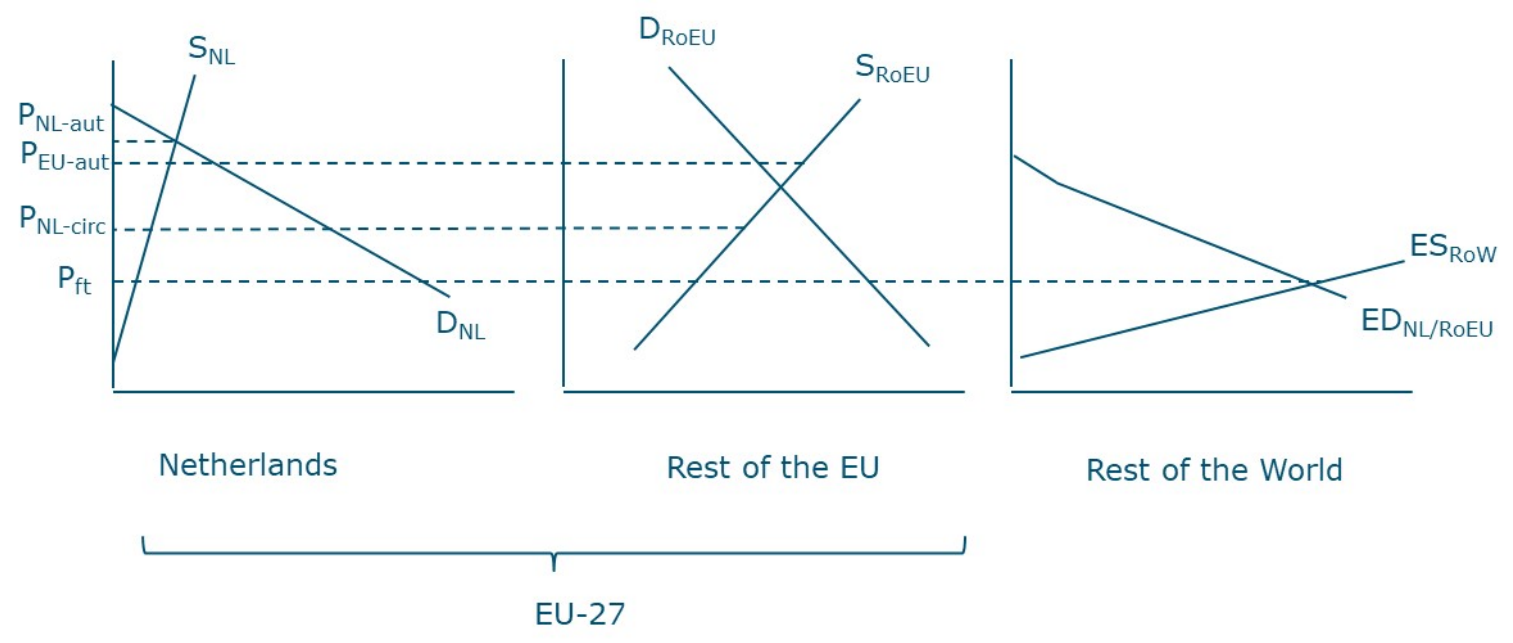

Figuur 2.1 Schematische weergave van de marktstructuur van eiwitrijk veevoer in het EDM-model

\subsection{Economie van kringloopsluiting op verschillende schaalniveaus}

De effecten van diverse manieren van het sluiten van de eiwitrijke veevoerkringloop worden hieronder geschetst aan de hand van figuur 2.1.

De uitgangssituatie, zonder beperkingen op de handel, geeft een relatief lage prijs ( $\mathrm{fft}_{\mathrm{ft}}$ van free trade).

Als Nederland voor een autarkie-scenario kiest, ontstaat een marktevenwicht waarbij de binnenlandse aanbod- en vraagcurve elkaar snijden. Dit leidt tot een hoge prijs $\mathrm{P}_{\mathrm{NL}-a u t}$. De hoge prijs lokt wat extra productie uit (vanuit de Nederlandse akkerbouw), maar zal vooral leiden tot een terugval van de vraag: door de relatief hoge krachtvoerprijs is een flink deel van de dierlijke sectoren niet langer concurrerend en zal er dus een forse krimp in deze sectoren gaan optreden.

Gaat Nederland niet uit de rest van de wereld importeren, maar betrekt het alle eiwitrijke veevoergrondstoffen uit de EU, dan zal dat tot de prijs PNL-circ leiden. Bij die prijs worden er namelijk voldoende eiwitrijke veevoergrondstoffen geproduceerd om aan de gestegen Nederlandse vraag naar EU-grondstoffen te kunnen voldoen. De prijs zal zeker hoger komen te liggen dan de prijs in de uitgangssituatie. Hoe hoog die prijs precies moet zijn wordt door het model berekend, waarbij er 
rekening mee wordt gehouden dat er allerlei aanpassingen in handelsstromen kunnen gaan plaatsvinden (bijvoorbeeld doordat de rest van de EU meer gaat importeren vanuit de rest van de wereld als Nederland niet langer gaat importeren).

Ten slotte, als de EU-27 besluit om niet langer eiwitrijke veevoergrondstoffen vanuit de rest van de wereld te importeren, zal dit weer tot een andere prijsstijging leiden ( $P_{E U}$-aut) die waarschijnlijk fors hoger zal zijn dan wanneer alleen Nederland besluit om 'circulair' te worden. Merk op dat Nederland in die situatie krachtvoer zal importeren uit de rest van de EU.

Sterke prijsstijgingen van eiwitrijke veevoergrondstoffen zullen de concurrentieverhoudingen van de Nederlandse en of Europese dierlijke sectoren aantasten: de hogere voerkosten (dan bij concurrenten in de rest van de wereld) zetten de rentabiliteit onder druk. In figuur 2.1 is dit aangegeven door de teruglopende vraag naar eiwitrijkveevoer bij hogere voerprijzen. Impliciet zit er achter dergelijke vraagcurves vaak een veronderstelling over de mate waarin de extra kosten kunnen worden doorberekend aan eindgebruikers en hoe die daar dan in hun consumptiepatroon (bijvoorbeeld vraag naar vlees en zuivelproducten) gaan reageren ${ }^{1}$. Juist op dat punt van die doorberekening van kosten (afwenteling op eindgebruikers) bestaat onzekerheid. De mate waarin dat mogelijk is zal heel sterk afhangen van het beleid dat verder in de EU en/of Nederland wordt gevoerd.

Als de consumenten bijvoorbeeld laaggeprijsde vleesproducten van buiten de EU kunnen kopen (import van eindproducten), dan is de afwentelingsruimte voor de producenten van dierlijke producten in de EU veel beperkter dan in het geval de EU de invoer van 'niet-circulaire' eindproducten aan de grens zal belasten en zo probeert om een fair level playing field te garanderen. In het laatste geval zullen de prijzen van dierlijke producten in zijn geheel stijgen. Naar verwachting zal de consumptie dan wel wat teruglopen, maar zullen veel consumenten dan een 'meerprijs' (moeten) betalen, die de rentabiliteit van de dierlijke sectoren dan ondersteunt (de opbrengstenstijging compenseert dan deels/geheel de voerkostenstijging).

Juist in het geval van extreme situaties is het nodig om de uitkomsten van het EDM-model goed in deze context te plaatsen. Het gebruikte model kan niet goed aangeven wat de gevolgen op de langere termijn zijn van structureel hoge eiwitrijke krachtvoederprijzen voor de dierlijke sectoren. Daarop van invloed zijn ook onzekere ontwikkelingen in het concurrentie- en handelsregime van de EU. Dit laatste is weer van belang voor de vraag in hoeverre hogere krachtvoerprijzen uiteindelijk kunnen worden doorberekend aan de eindgebruikers van dierlijke producten. Dat deel is niet endogeen in het EDMmodel meegenomen en viel buiten de directe scope van dit project.

\footnotetext{
1 Het verbruik van dierlijke producten kan ook wijzigen door veranderingen in de preferenties van consumenten (bijv. een toename van het aantal vegetariërs of flexitariërs). Die ontwikkeling is onderdeel van de baseline waarmee de uitkomsten van de scenario's worden vergeleken.
} 


\section{Referentiescenario: kleine daling veestapel in Nederland}

\section{$3.1 \quad$ Inleiding}

Dit hoofdstuk beschrijft het referentiescenario aan de hand van de EU-landbouwvooruitzichten (EC, 2019). Hierop aansluitend zijn projecties voor Nederland opgesteld (Lesschen et al., 2020). De vooruitzichten zijn een vooruitblik voor de belangrijkste landbouwmarkten in de EU tot 2030 en gebaseerd op veronderstellingen over internationale marktontwikkelingen, macro-economische omstandigheden, het weer en het landbouw- en handelsbeleid. Hierbij is uitgegaan van aannemelijke en coherente veronderstellingen en een ongewijzigd landbouw- en handelsbeleid. Er wordt uitgegaan van relatief stabiele ontwikkelingen. Omdat werkelijke ontwikkelingen vaak onstabiel zijn, moeten de vooruitzichten niet als voorspelling worden opgevat.

\subsection{Rundvee}

Volgens de vooruitzichten van de Europese Commissie zal het aantal melkkoeien in de EU licht dalen, maar groeit de productie van melk door naar 167,8 mln. ton in 2030 ten opzichte van 153,1 mln. ton in 2020. De melkproductie per koe neemt dus verder toe. De groei van de productie gaat in een lager tempo dan in eerdere perioden, mede door milieumaatregelen (EC, 2019). In 2030 zal de biologische melkproductie in de EU 7\% uitmaken van de totale melkproductie (in 2017 lag dit aandeel op 3\%). GMO-vrije, dierenwelzijn- en andere gecertificeerde melkproductiesystemen zullen ook marktaandeel winnen.

Herkauwers nemen $5 \%$ van de totale uitstoot van broeikasgassen in de EU voor hun rekening. Naar verwachting worden maatregelen getroffen om deze uitstoot te verminderen, wat de ontwikkeling van de melkproductie in de EU zal beïnvloeden. Momenteel worden er al verschillende maatregen genomen, zoals bij de voeding van runderen. Daarnaast zullen ook zuivelverwerkers op termijn maatregelen introduceren. Enkele zuivelverwerkers hebben als langetermijndoelstellingen om $\mathrm{CO}_{2}-$ neutraal te worden door middel van methaanreductie en verbetering van koolstofvastlegging (EC, 2019).

De twee laatste vee-enquêtes van de EU lieten een daling van de productie van rundvlees zien in de belangrijkste EU-lidstaten, met uitzondering van Polen en Spanje. Deze trend zal de komende jaren mogelijk doorzetten. Ondanks een lichte stijging van het gemiddelde slachtgewicht tegen 2030, zal de brutorundvleesproductie in de EU blijven dalen. Deze productiedaling zal zich afspelen tegen de achtergrond van licht stijgende voer- en rundvleesprijzen na 2025 (EC, 2019). 


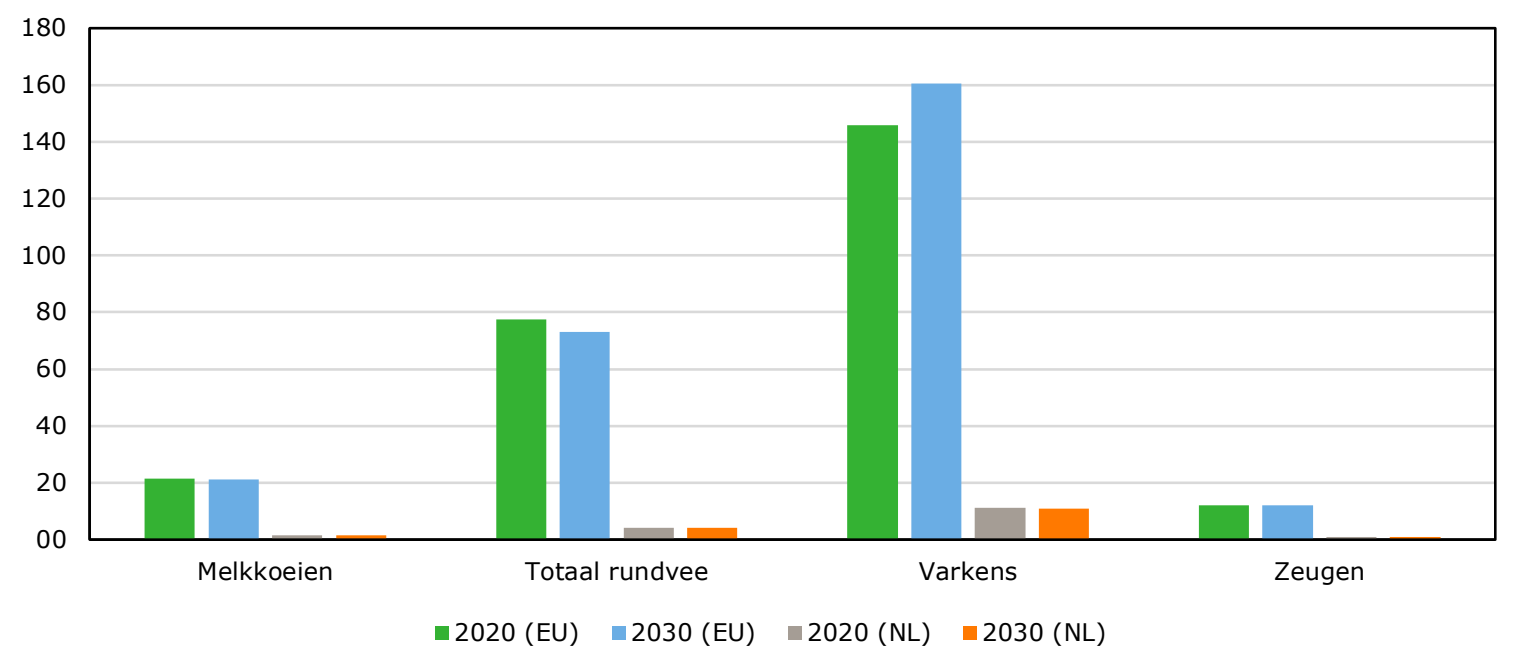

Figuur 3.1 Aantal dieren in de EU en Nederland ( $x \quad 1 \mathrm{~m} / \mathrm{n}$.

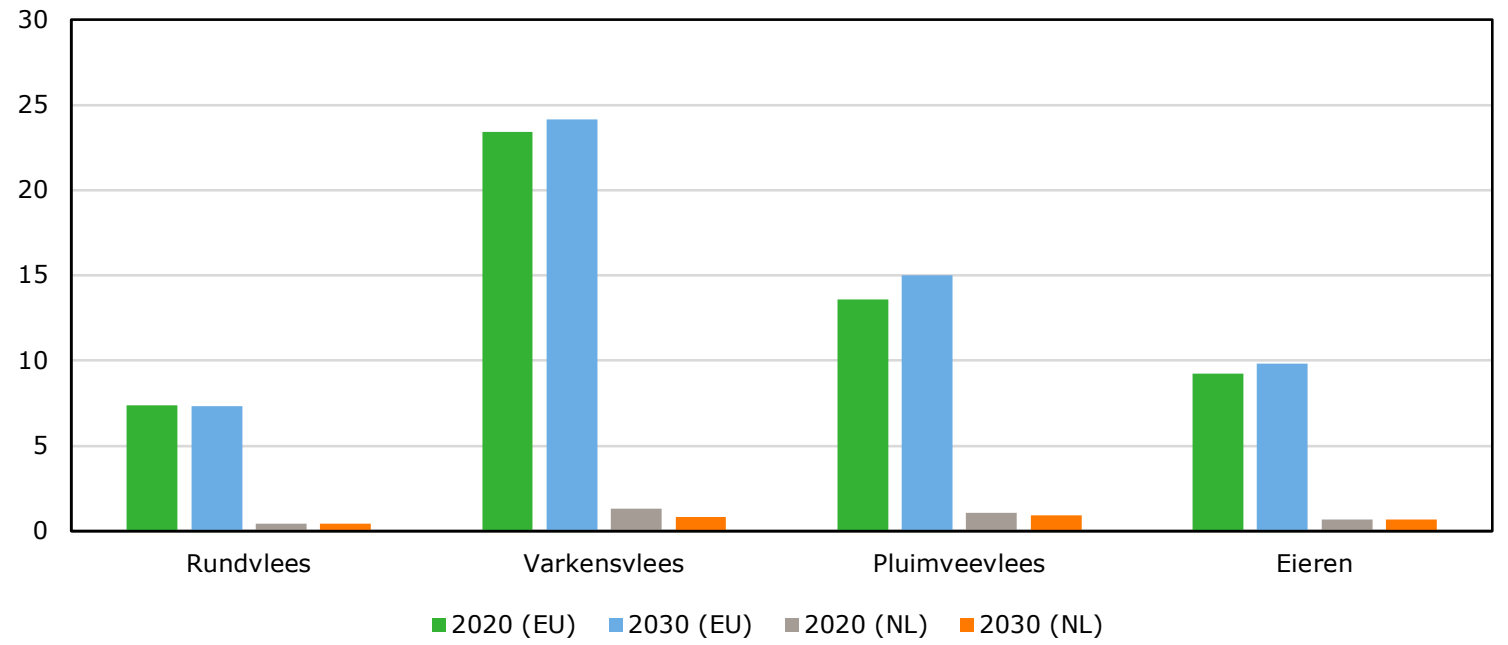

Figuur 3.2 Productievolume rundvlees, varkensvlees, pluimveevlees en eieren in EU en Nederland (m/n.ton)

In Nederland zal de productie van melk doorgroeien tot $14,8 \mathrm{mln}$. ton in 2030 ten opzichte van $13,9 \mathrm{mln}$. ton in 2020. Ondanks dat de melkproductie toeneemt zal het aantal melkkoeien in Nederland dalen van 1,64 mln. in 2020 naar 1,57 mln. in 2030. In de recent uitgevoerde sectorstudie (Beldman et al, 2020) wordt op basis van een meer gedetailleerde inschatting van de beleidsontwikkelingen een melkproductie van 14,6 mln. ton in 2030 verwacht, bij een veestapel van 1,48 mln. dieren. Door de groeiende melkproductie per koe past er meer melk binnen het systeem van fosfaatrechten. In de eerste jaren blijft de melkproductie echter stabiel omdat fosfaatrechten uit de markt worden gehaald als gevolg van opkoopregelingen in het kader van het aangekondigde stikstofbeleid (Beldman et al., 2020). Voor klimaat (broeikasgasemsisie) en ammoniak worden bij deze productieontwikkeling de ingeschatte doelstellingen niet gehaald en zullen er in de toekomst extra technische maatregelen nodig zijn en wanneer deze onvoldoende zijn, zou dit op termijn tot een nog verdere krimp van de veestapel kunnen leiden. 


\subsection{Varkens}

De productie van varkensvlees zal volgens de vooruitzichten doorgroeien tot $24,1 \mathrm{mln}$. ton in 2030 ten opzichte van 23,4 mln. ton in 2020. De vooruitzichten zijn onzeker gezien de uitbraak van de Afrikaanse varkenspest in Aziatische landen. Vooral China is hard geraakt door de uitbraak. Door deze crisis zal de wereldwijde importvraag naar varkensvlees toenemen en de productie van varkensvlees in de EU de komende tijd toenemen. Door de moderniseringsslag die nu in China plaatsvindt, zou op de middellange termijn de concurrentie voor de EU kunnen toenemen (Jongeneel et al., 2020). Vanwege de crisis is de export van varkensvlees in 2019 aanzienlijk gestegen. Volgens de prognoses wordt deze stijging doorgezet tot 2022. Na 2022, wanneer de Chinese productie is hersteld, zullen de prijzen van varkensvlees weer dalen, wat ook kan leiden tot een daling van de productie in de EU (EC, 2019).

In het basisscenario van Velthof et al. (2019) neemt het aantal varkens in Nederland in 2025 af met ruim $5 \%$ ten opzichte van 2018 , en zal dit niveau vervolgens gehandhaafd blijven. De krimp is het gevolg van de Saneringsregeling Varkenshouderij (SVR). De krimp vindt voor twee derde plaats bij vleesvarkens en een derde bij zeugen. Overigens kan de belangstelling voor de SRV afnemen als gevolg van de hoge varkensprijzen die samenhangen met de Afrikaanse Varkenspest. In de outlook is er rekening mee gehouden dat op termijn de zeugenstapel toch nog wat kan gaan groeien omdat door de milieubeperkingen de zeugenhouderij economisch gezien aantrekkelijker wordt dan de mesterij (terwijl de dierrechten binnen de sector tussen zeugen en vleesvarkens uitwisselbaar zijn).

\section{$3.4 \quad$ Pluimvee}

Volgens de vooruitzichten van de EU groeit de productie van pluimveevlees in de EU de komende jaren door van 13,6 miljoen ton in 2020 naar 15 miljoen ton in 2030 (figuur 3.2). Deze stijging in productie komt voort uit een toenemende vraag. Al jaren stijgt de vraag geleidelijk doordat pluimveevlees veel voordelen kent bij de consument (betaalbaarheid, gemak, gezond imago, en beperkte uitstoot van broeikasgassen). Door aanzienlijke investeringen en lagere kosten zal de productiegroei vooral toenemen in de lidstaten die na 2004 lid zijn geworden van de EU (EU-n13). Verwacht wordt dat de komende jaren de productie van pluimvee vlees zal blijven groeien in de EUn13-lidstaten, terwijl die in de overige lidstaten zal vertragen en stabiliseren. Waar de productie in de EU als geheel zal toenemen, zal de productie van pluimvee in Nederland waarschijnlijk iets afnemen.

In Nederland is uitbreiding van de pluimveestapel niet mogelijk. Door pluimveerechten is er een bovengrens van het aantal pluimvee dat gehouden mag worden. Deze rechten gelden nog tot zeker 2028. Momenteel worden deze rechten volledig benut. De marktvraag en concurrentie bepalen of dit zo zal blijven. In Nederland en omringende landen blijft de vraag stabiel of neemt deze toe. Recent ondertekende handelsakkoorden van de EU met enkele landen zal niet leiden tot grote verandering in de invoer van vlees van pluimvee en eieren uit derde landen. In deze akkoorden worden pluimveeproducten uitgesloten (Canada) of worden beperkte quota gegeven (Mexico). De invoer van pluimveeproducten uit Oekraïne neemt wel toe (Velthof et al., 2019).

\section{$3.5 \quad$ Veevoer}

Diervoeders, inclusief voedermiddelen en mengvoeders, vormen de belangrijkste input voor de veehouderij (Fefac). Binnen de EU-28 wordt jaarlijks ongeveer $833 \mathrm{mln}$. ton voer door vee verbruikt. Van deze hoeveelheid is $559 \mathrm{mln}$. ton als ruwvoer geteeld en gebruikt. Het saldo, ofwel $274 \mathrm{mln}$. ton voer, is inclusief granen die op de boerderij worden geteeld en verbruikt ( $70 \mathrm{mln}$. ton) en voer dat door veehouders is aangekocht als aanvulling op hun eigen voedermiddelen (zowel enkelvoudige voedermiddelen als mengvoer). In 2019 werd in de EU-28 bijna $165 \mathrm{mln}$. ton mengvoer geproduceerd (tabel 3.1), circa $80 \%$ van alle aangekochte diervoeders. Bijna $15 \mathrm{mln}$. ton hiervan werd binnen Nederland geproduceerd ( $9 \%)$, waarvan een deel bestemd is voor de buitenlandse markt. 
Tabel 3.1 Industriële mengvoerproductie (m/n. ton) in de EU-28 en Nederland, 2019

\begin{tabular}{lrrrr} 
& Rundvee & Varkens & Pluimvee & Totaal \\
EU-28 & 47,6 & 52,0 & 56,1 & 165,0 \\
\hline Nederland & 4,5 & 5,0 & 4,0 & 14,7 \\
\hline
\end{tabular}

Bron: https://fefac.eu/wp-content/uploads/2021/02/FF_2020_Final.pdf.

Eiwitarm voer (voer met minder dan 15\% eiwit) vertegenwoordigt bijna $60 \%$ van de grondstoffen die in de EU voor voer worden gebruikt (in volume). Dit bestaat grotendeels uit de granen tarwe en mais. Volgens de prognoses zal dit in de komende 10 jaar niet veranderen. In deze periode zal het totale volume aan voedergraan voor $40 \%$ bestaan uit mais en $30 \%$ uit tarwe. Naast deze voedergranen is een groot deel voer afkomstig van grasland. Geschat wordt dat $940 \mathrm{mln}$. ton gras als voer (met een eiwitgehalte van ongeveer 2,5\%) is verbruikt in de EU in de periode 2018/2019 (EC, 2019 en zie ook tabel 1.1 in dit rapport).

Peulvruchten zoals erwten en gedroogde granen (eiwitgehalte tussen $15 \%$ en $30 \%$ ) maken steeds vaker deel uit van het voerrantsoen in de EU, al is de toepassing ervan moeilijk uit te breiden vanwege een relatief hoge prijs in vergelijking met andere veevoergrondstoffen. Desalniettemin zal volgens de prognoses het gebruik van peulvruchten toenemen dankzij de toenemende vraag naar lokaal geproduceerde en/of niet-genetisch gemodificeerd voer en het toegenomen gebruik van peulvruchten binnen vruchtwisselingssystemen (EC, 2019).

\section{Conclusie}

Eiwitrijk voer (zoals sojaschroot, vismeel een magere melkpoeder) zal bij ongewijzigd beleid ook in de komende 10 jaar een belangrijk deel uit blijven maken van het voerrantsoen. Volgens de vooruitblik zal in 2030 in de EU ongeveer $57 \mathrm{mln}$. ton eiwitrijk voer worden geconsumeerd. Sojaschroot zal naar verwachting het meeste worden toegepast als voer. Het gebruik ervan kan oplopen tot $31 \mathrm{~m} / \mathrm{n}$. ton (EC, 2019). 


\section{$4 \quad$ Alleen Nederlands veevoer: sterke reductie veestapel}

\section{$4.1 \quad$ Inleiding}

De omvang van de Nederlandse veehouderij is in dit scenario direct gekoppeld aan het Nederlands voer. Om de gevolgen inzichtelijk te maken, zijn berekeningen gemaakt voor de sectoren melkvee, varkens en pluimvee. Hierbij is gebruikgemaakt van het programma Feedprint (versie juni 2020). In dit programma wordt per voersoort de samenstelling in veevoergrondstoffen met de bijbehorende herkomst gegeven. Zo is inzichtelijk welk deel van de grondstoffen uit Nederland komt. Voordat de bevindingen worden gepresenteerd, worden enkele resultaten uit eerder onderzoek toegelicht.

\subsection{Enkele uitkomsten uit eerder onderzoek}

\section{Landvoetafdruk drie keer Nederland}

Nederland is een klein dichtbevolkt land met veel mensen en veel dieren en een hoog niveau van consumptie (CLO, 2020). Er is feitelijk te weinig ruimte voor wonen, verkeer, natuur, recreatie en landbouw. Door het luxe leefpatroon heeft de Nederlander een hoge landvoetafdruk. Het totale landgebruik binnen en buiten Nederland is becijferd op 10,4 $\mathrm{mln}$. ha, driemaal de totale oppervlakte van Nederland (zie figuur 4.1). Bijna de helft van het landgebruik is voor de behoefte aan hout en papier (4,75 mln. ha). Daarna volgt vlees/zuivel $(1,90 \mathrm{mln}$. ha) en overige voeding $(1,44 \mathrm{mln}$. ha, onder andere varkens en pluimvee) en kleding/textiel $(0,34 \mathrm{mln}$. ha). Voorbeelden van landgebruik in het buitenland zijn hout uit Scandinavië, katoen uit Turkije en voor de landbouw betreft het landgebruik voor graan uit Frankrijk en soja uit Brazilië.

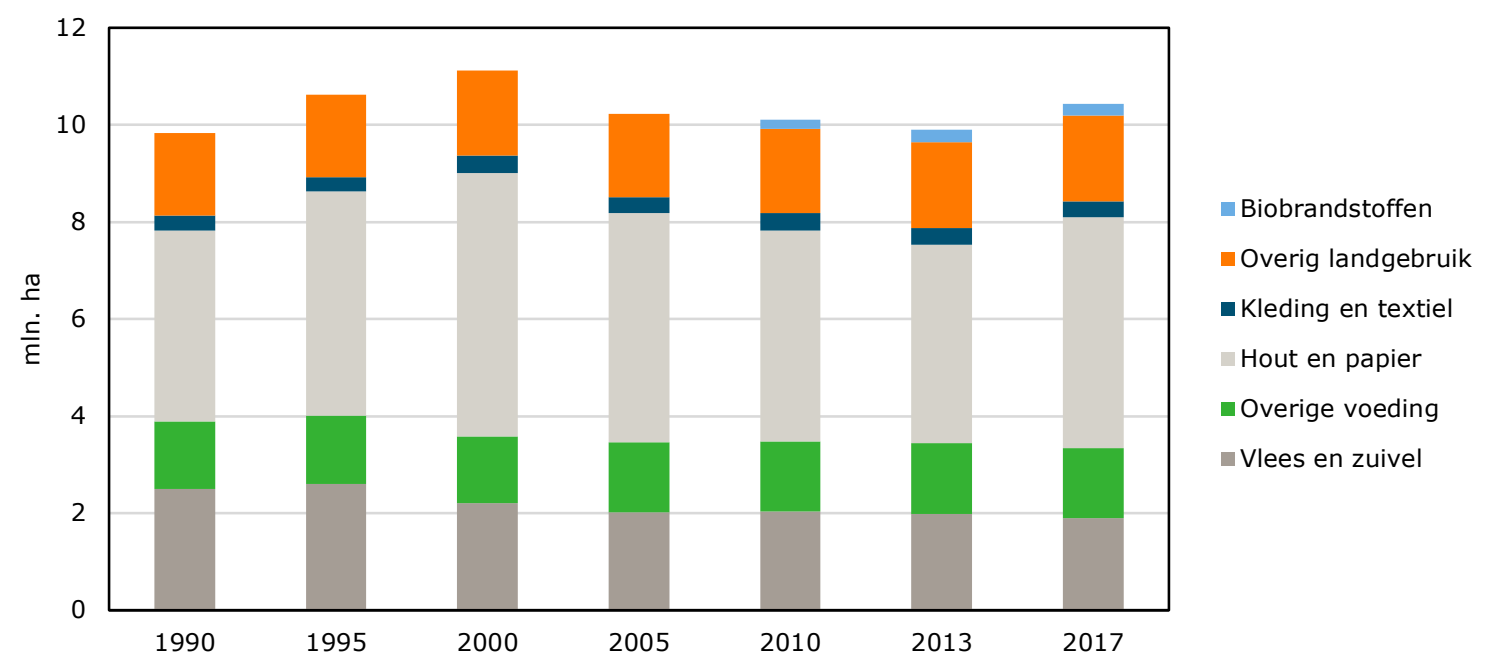

Figuur 4.1 Mondiaal landgebruik door Nederlandse consumptie Bron: PBL (wWw.clo.nl/nl007509).

Het landgebruik voor de consumptie van voedsel bedraagt rond de 0,2 ha per hoofd van de bevolking. De belangrijkste voedselproducten hierin zijn rundvlees, zuivel en varkensvlees. Veel landbouwgrond is nodig voor de productie van veevoer (voornamelijk granen en soja) en voor gebruik als weiland. Het landgebruik voor de voedselconsumptie in 2017 (3,3 mln. ha) bedraagt anderhalf maal het agrarisch areaal van Nederland (2,2 mln. ha). In 1990 bedroeg het landgebruik voor voedselconsumptie nog $3,9 \mathrm{mln}$. ha (zie figuur 4.1). Ondanks een bevolkingsgroei van bijna $15 \%$ sinds 1990 is het 
ruimtebeslag voor voeding dus afgenomen. Dit komt vooral door toegenomen opbrengsten in de landbouw (CLO, 2020).

Forse terugloop aantal dieren en daling export

Er zijn verschillende studies die een beeld geven van de situatie waarin Nederland geen veevoer invoert (zie bij voorbeeld Berkum et al., 2019). In de studie van Terluin et al. (2013) is berekend of Nederland de eigen bevolking zou kunnen voeden zonder in- en uitvoer. Belangrijk uitgangspunt in de studie is de sterk vereenvoudigde inrichting van de Nederlandse landbouw en minimalisatie van het grondgebruik. Ook wordt gerekend met drie alternatieve voedselpakketten (een karig menu, het huidige menu en een gezond menu). In de autarkiesituatie wordt het gehele landbouwareaal ingezet voor de landbouwproductie en de opbrengst per hectare en per dier is gelijk aan het huidige niveau (hoog) of op een lager niveau (laag). Het optimalisatiemodel berekent de situatie bij zes scenario's. Voor onze studie is vooral het scenario 'gezond voedselpakket - hoge productie' van belang. Tabel 4.1 geeft de resultaten bij dit scenario.

Tabel 4.1 Autarkiesituatie bij het scenario 'gezond voedselpakket - hoge productie' ten opzichte van de referentie situatie

\begin{tabular}{lr} 
Diersoort & Aantal dieren (\%) \\
Melkkoeien & 60 \\
\hline Varkens & 0 \\
\hline Vleeskuikens & 48 \\
\hline Leghennen & 57 \\
\hline
\end{tabular}

Bron: Terluin et al. (2013).

In de autarkiesituatie kan nog circa $60 \%$ van het aantal melkkoeien en leghennen gehouden worden. Het aantal vleeskuikens komt uit op bijna $50 \%$ van het aantal in de referentie situatie. Het aantal varkens is nul. Dit is het gevolg van de keuze dat varkensvlees niet in het menu is opgenomen. De studie verkiest vleeskuikens voor de vleesvoorziening boven varkens, omdat de voederconversie (voerverbruik per kilogram vlees) voor vleeskuikens voordeliger is dan die voor varkens.

Technische oplossing versus reductie veestapel

Volgens De Wolf et al. (2019) vervult de veehouderij een belangrijke rol in de kringlooplandbouw. Dieren verwaarden reststromen en de nutriënten uit de mest kunnen weer benut worden in de plantaardige productie. De Wolf richt zich op de ophoping van nutriënten (met als voorbeeld fosforstromen) en presenteert twee denkrichtingen die een oplossing kunnen bieden.

De eerste oplossing is een technische: Nederland is een land waar veel dieren en veel mensen samenleven. Met nutriënten wordt efficiënt omgegaan. Verliezen worden voorkomen door het terugwinnen van nutriënten uit rioolslib en de mestverwerkingsindustrie. Deze teruggewonnen nutriënten gaan naar de veevoer producerende gebieden. In feite is dit de huidige oplossingsrichting die Nederland gekozen heeft. De omvang van de landbouw, veehouderij en agro-industrie blijft gehandhaafd met mestverwerking en export als technische oplossing (De Wolf, 2019).

De andere oplossingsrichting betreft het verminderen van het aantal dieren doordat er geen veevoer geïmporteerd wordt. De dieren worden dan gehouden in de landen die de veevoer telen. Voor de landbouw, veehouderij en agro-industrie betekent dit een sterke afname van de sectoren. Er wordt geen mest geëxporteerd en de voedselexport neemt sterk af. Binnen de veehouderij zal vooral de omvang van de hokdierenhouderij (varkens, pluimvee) fors afnemen. De Wolf geeft aan dat de afname van de landbouwsector aanzienlijke economische schade geeft voor het Nederlandse agrofoodcomplex, omdat de export van producten sterk afneemt en de schaalvoordelen verloren gaan. Hier tegenover staan voordelen, zoals minder milieugerelateerde problemen (emissies, stank) en lagere kosten voor beschermingsmaatregelen voor natuur en landschap (De Wolf, 2019). 


\subsection{Rundvee}

In de melkveehouderij komt een belangrijk deel van het voer van het eigen bedrijf. Het ruwvoer wordt in Nederland geteeld en bestaat voornamelijk uit graskuil, hooi, snijmailkuil en weidegras. Dit ruwvoer wordt aangevuld met aankoop van krachtvoer, enkelvoudige veevoergrondstoffen en natte bijproducten. Het krachtvoer bestaat voor een groot deel uit buitenlandse grondstoffen. Het aandeel ruwvoer en de hoeveelheid aangekochte natte bijproducten verschillen sterk tussen de bedrijven. Ook zijn er verschillen tussen regio's en per seizoen. Afhankelijk van het weer en het groeiseizoen zijn er ook verschillen tussen de jaren. Ook de samenstelling van het krachtvoer kan verschillen door wijzigingen in aanbod, prijzen van grondstoffen, wisselkoersen en andere factoren. In deze paragraaf beschrijven we de gemiddelde situatie om zo een schatting te geven van het aandeel Nederlands veevoer te geven.

In de CBS-rapportage dierlijke mest en mineralen, 1990-2018 (Van Bruggen en Gosseling, 2019) worden gedetailleerde overzichten gegeven van de voeropname door melk en kalfskoeien. Hierbij wordt een indeling gemaakt naar regio (Zuidoost-Nederland en Noordwest-Nederland) en wordt er onderscheid gemaakt naar stalperiode en weideperiode. Op basis van de cijfers voor 2018 kan berekend worden dat gemiddeld in Nederland 65\% van het hoeveelheid droge stof afkomstig is van ruwvoer. Dit is ruwvoer in de vorm van snijmais, graskuil/hooi en vers gras. Hoewel er ook snijmais wordt ingevoerd in Nederland, kunnen we veronderstellen dat het ruwvoer voor melkvee bijna volledig uit Nederland komt. De CBS-rapportage geeft aan dat in 2018 5\% van het voer voor melkvee bestond uit vochtrijk krachtvoer. Dit zijn bijproducten van de levensmiddelenindustrie, zoals bierborstel, aardappelpersvezel, bietenperspulp en maisgluten. Hoewel deze producten van de Nederlandse industrie komen, heeft maar een deel van grondstof als herkomst Nederland. De overige $25 \%$ van het rantsoen is krachtvoer en enkelvoudige veevoergrondstoffen.

Volgens Feedprint (versie juni 2020) bestaat het standaardkrachtvoer uit meerdere grondstoffen. De belangrijkste zijn mais, palmpitschroot, suikerbietenpulp, tarwe, raapzaadschroot, tarwegluten, vinasse/melasse. Van deze grondstoffen is 10 tot $20 \%$ afkomstig uit Nederland, namelijk een deel van de tarwe, raapzaad en het suikerbietenpulp en vinasse/melasse (bijproduct suikerindustrie). Wordt voor elk onderdeel van het rantsoen het aandeel Nederlandse herkomst opgeteld, dan kan geconcludeerd wordt dat circa $70 \%$ van het rantsoen voor melkvee afkomstig is uit Nederland. Als de melkkoeien uitsluitend gevoerd worden met veevoer afkomstig uit Nederland, bevat het voer minder eiwit. Vooral in het krachtvoer komen de eiwitrijke grondstoffen uit derde landen. Het gevolg van een minder eiwitrijk voer is een lagere melkgift. Hierdoor kan de melkgift per koe 5 tot $10 \%$ lager uitkomen (Daatselaar, 2020). Dit bekent dat, gemeten in melkvolume, de productie bij Nederlands voer lager uitkomt, naar schatting op $65 \%$.

\subsection{Varkens}

Het merendeel van de bedrijven met vleesvarkens is niet grondgebonden. Bedrijven met vleesvarkens kopen mengvoer bij een mengvoerfabrikant. Een deel van de bedrijven koopt natte bijproducten voor brijvoeding. Het merendeel van het voer bestaat uit mengvoer, soms aangevuld met losse grondstoffen die de varkenshouder apart aankoopt. De losse grondstoffen zijn vaak gelijk aan de grondstoffen in het mengvoer. Gemiddeld voor heel Nederland is het aandeel natte bijproducten circa $10 \%$ van het rantsoen (Hoste, 2020).

Volgens Feedprint 2020 bestaat het voer voor vleesvarkens voor circa 70\% uit granen. De granen tarwe, gerst, rogge en triticale worden veel gebruikt in varkensvoer. Overige veevoergrondstoffen in het mengvoer zijn raapzaad, melasse, palmpitschroot en sojaschroot. De herkomst van de grondstoffen is zeer divers. Granen komen uit de omringende landen en voor een deel uit Nederland. Raapzaad en melasse komt ook, voor een deel, uit Nederland. Van alle grondstoffen in het krachtvoer komt circa $15 \%$ uit Nederland. Aangevuld met de natte bijproducten komt dan 15 tot $20 \%$ van de grondstoffen in het rantsoen van varkens uit Nederland. Door meer tarwe en raapzaad te gebruiken, kan het aandeel met Nederlandse herkomst verhoogd worden naar 25 tot 30\%. Vleesvarkensvoer 
heeft een eiwitpercentage van 15 tot $18 \%$. De herkomst van de eiwithoudende grondstoffen is van landen buiten de EU. Een verlaging van het eiwitpercentage geeft mindere productieresultaten. Vooral de dagelijkse groei van de vleesvarkens wordt lager.

\subsection{Pluimvee}

\section{Leghennen}

Bijna alle bedrijven in Nederland voeren leghennen met aangekocht mengvoer. Slechts enkele bedrijven hebben landbouwgrond, waar ze eventueel gewassen verbouwen om te voeren aan de leghennen. Tarwe en korrelmais zijn geschikt om, zonder verdere bewerking, direct aan leghennen te voeren. Volgens Feedprint (juni 2020) bestaat leghennenvoer (legmeel gevoerd in de productie) voor meer dan $60 \%$ uit granen (korrelmais en tarwe). De benodigde eiwitten komen van sojaschroot of sojabonen met een aandeel van $15 \%$. Naast soja wordt ook eiwitrijk zonnebloemenschroot of raapzaadschroot gebruikt. Een deel van de tarwe en van het raapzaadschroot heeft als herkomst Nederland. In totaal heeft 10 tot $15 \%$ van het leghennenvoer als herkomst Nederland. Door een deel van de mais te vervangen door tarwe en een deel van soja te vervangen door raapzaadschroot kan het aandeel verhoogd worden tot bijvoorbeeld 25\%. Legmeel heeft een eiwitpercentage van 15 tot $17 \%$. Bij een verdere verlaging van het aandeel soja wordt het eiwitgehalte zodanig laag dat dit ten koste gaat van de productie en de kwaliteit van de eieren.

\section{Vleeskuikens}

Veel bedrijven in Nederland voeren vleeskuikens met aangekocht mengvoer. Een deel van de bedrijven heeft akkerbouw met daarnaast vleeskuikens. Deze bedrijven kunnen de eigen geteelde tarwe voeren aan de vleeskuikens op het eigen bedrijf. Als eigen geteelde tarwe gevoerd wordt, dan wordt hiernaast kernvoer aangekocht met daarin minder tarwe (Van Horne, 2020). Volgens Feedprint (juni 2020) bestaat vleeskuikenvoer (groeivoer, vanaf 2 weken leeftijd) voor meer dan $60 \%$ uit granen (korrel mais en tarwe). De benodigde eiwitten komen van sojaschroot of sojabonen met een aandeel van $25 \%$. Een deel van de tarwe heeft als herkomst Nederland. In totaal heeft circa $10 \%$ van het vleeskuikenvoer als herkomst Nederland. Door een deel van de mais te vervangen door tarwe en een deel van soja te vervangen door raapzaadschroot of aardappeleiwit, kan het aandeel verhoogd worden tot bijvoorbeeld 20\%. Vleeskuikenvoer heeft een eiwitpercentage van 18 tot $22 \%$. Vooral de jonge kuikens krijgen voer met een hoog eiwitgehalte. Bij een verdere verlaging van het aandeel soja wordt het eiwitgehalte zodanig laag dat dit ten koste gaat van de productie en de groeisnelheid van de kuikens.

\subsection{Conclusie}

De volgende percentages van de huidige veestapel kunnen worden gevoerd met uitsluitend voer van Nederlandse herkomst (tabel 4.2).

Tabel 4.2 Reductie van veestapel bij uits/uitend voer van Nederlandse herkomst, in \%

$\begin{array}{lrr}\text { Sector } & \text { Zonder aanpassing } & \text { Met kleine aanpassing van de } \\ \text { voersamenstelling }\end{array}$

Wanneer voor de Nederlandse veestapel alleen veevoer van Nederlandse herkomst beschikbaar is, zijn extreme reducties in de varkens- en pluimveestapel dus onvermijdelijk. 


\section{$5 \quad$ Alleen Europees veevoer: hogere voerkosten}

\section{$5.1 \quad$ Inleiding}

Dit hoofdstuk beschrijft de samenstellingen en prijzen van Nederlandse veevoeders die geformuleerd zijn met extra randvoorwaarden om de voermestkringloop te sluiten ('circulair veevoer'). De volgende varianten zijn hierbij onderzocht:

- Basis = situatie zonder extra voorwaarden

- Variant 1 = geen soja in het voer

- Variant 2 = veevoergrondstoffen uit de EU-27 plus VK

- Variant 3 = veevoergrondstoffen uit Europa.

Toelichting varianten

Basis = berekening op basis van standaarduitgangspunten en nutritionele voorwaarden, waarbij het verbruik van alle reguliere grondstoffen is toegestaan.

Variant 1. Uitsluiting van alle producten van soja, zoals getoaste sojabonen, sojaschroot, sojahullen of sojaolie. Omdat EU soja maar in beperkte mate beschikbaar is, wordt alle soja uitgesloten in deze variant.

Variant 2. Uitsluiting van alle grondstoffen die de EU importeert uit derde landen. Naast alle soja producten zijn dit producten zoals palmpitschilfers, palmolie, rietmelasse, citrus pulp en zoete lupine. Vismeel met $65 \%$ eiwit komt uit Zuid-Amerika is dus ook uitgesloten (ter onderscheid van vismeel met $70 \%$ eiwit uit Scandinavië).

Variant 3. Uitsluiting van alle grondstoffen van landen buiten Europa. In deze definitie hoort Oekraïne bij Europa en zijn grondstoffen uit deze regio beschikbaar. In deze variant zijn specifieke grondstoffen die afkomstig zijn uit Oekraïne toegelaten, zoals zonnebloemschilfers. Door een speciale manier van bewerking voor de oliewinning worden deze schilfers ('expellers') alleen aangeboden door Oekraïne. Zonnebloemschroot met 37\% eiwit komt ook uit Oekraïne (ter onderscheid met zonnebloemschroot met $27 \%$ eiwit afkomstig uit de EU). Ook granen en mais kunnen uit de Oekraïne komen, maar hierbij is het niet mogelijk in de berekeningen een onderscheid te maken naar herkomst.

De berekeningen zijn uitgevoerd door Schothorst Feed Research (SFR). SFR berekent de optimale samenstelling van een mengvoer waarbij voldaan wordt aan de nutritionele voorwaarden (onder andere voor energieniveau en eiwitpercentage) en de bijbehorende grondstoffen eisen (onder andere minimaal of maximaal percentage van een grondstof). Het resultaat is een samengesteld voer, dat voldoet aan alle eisen voor de laagste prijs. Alle uitgangspunten en voorwaarden sluiten aan bij de huidige gangbare praktijk van de Nederlandse veevoerbedrijven. Alle voeders bevatten een premix (met mineralen en vitaminen) ingerekend tegen de gangbare prijzen.

De prijzen van de veevoergrondstoffen zijn van oktober 2020 (exclusief btw en franco veevoerfabriek). De berekende prijs van de veevoergrondstoffen wordt verhoogd met een toeslag voor de veevoerfabriek (mengen, persen, transport en marge). De gepresenteerde prijs geeft een indicatie van de prijs die de veehouder betaalt bij levering op zijn bedrijf. Voor rundveebrok is gerekend met een toeslag van 5 euro per $100 \mathrm{~kg}$ en voor alle pluimvee en varkens voeders is de toeslag 4 euro per $100 \mathrm{~kg}$.

In Nederland werd in 2019 in totaal 11,4 mln. ton mengvoer geproduceerd voor de Nederlandse veehouderij (Nevedi, 2020). Hiervan gaat 4,1 mln. ton naar rundvee, 4,3 mln. ton naar varkens $3,0 \mathrm{mln}$. ton naar pluimvee. Per sector worden meerdere soorten voer gebruikt. Tabel 5.1 geeft een overzicht van de soorten voeders en het aandeel in het totale volume per sector. 
Tabel 5.1 Hoeveelheden voer per diersoort en de voedersoorten (aandeel) per sector

\begin{tabular}{lllr} 
Diersoort & hoeveelheid $(\mathrm{mln}$. ton) & voeder soort & aandeel (\%) \\
Rundvee & 4,1 & A-brok & 20 \\
\hline & B-brok & 20 \\
\hline Varkens & 4,3 & Eiwitrijke brok & 65 \\
\hline & Vleesvarkens & 7 \\
\hline & Zeug lacto & 15 \\
\hline Pluimvee & Zeug dracht & 13 \\
\hline & Biggen & 5 \\
\hline & Opfok leghennen & 45 \\
\hline & Leghennen & 5 \\
\hline & Vleeskuikenouderdieren & \\
\hline & Vleeskuikens & \\
\hline
\end{tabular}

Per sector zijn de belangrijkste voeders doorgerekend. Voor rundvee is dat A-brok, B-brok en eiwitrijke brok (paragraaf 5.2). Voor de varkenshouderij voer voor vleesvarkens, drachtige zeug en biggen (paragraaf 5.3). Voor pluimveevoer voor leghennen, vleeskuikens start en vleeskuikens groeivoer (paragraaf 5.4).

SFR heeft ook de optie voor gebruik van diermeel (verwerkt dierlijk eiwit) doorgerekend voor pluimvee en varkensvoerders. De resultaten van deze variant worden beschreven in paragraaf 5.5.

\subsection{Rundvee}

Bij rundvee is 65 tot $70 \%$ van het voer ruwvoer. Dit ruwvoer bestaat uit gras, graskuil of snijmaiskuil. Dit ruwvoer komt grotendeels van het eigen bedrijf. Circa 20 tot $25 \%$ van het voer voor melkvee komt via mengvoer (Van Bruggen, CBS 2019). Dit mengvoer wordt aangekocht van mengvoerfabrieken. Er kunnen drie soorten rundveebrok onderscheiden worden. Naast A-brok (basisbrok, aandeel 20\%) wordt vooral B-brok (iets meer eiwit, aandeel 60\%) gebruikt. In een rantsoen met veel snijmais wordt eiwitrijke brok gebruikt (hoog gehalte eiwit, aandeel 20\%). Voor deze drie soorten rundveebrok zijn de varianten doorgerekend.

\section{A-brok}

In deze studie is A-brok een rundveebrok met 13,9 ruw eiwit. In de basissituatie zit geen soja in de A-brok. Hierdoor is het voer in variant 1 exact gelijk aan de basissituatie (tabel 5.2). In variant 2 is het niet mogelijk palmpitschilfers (afkomstig uit Azië) te gebruiken. De samenstelling verandert, waarbij gerst wordt vervangen door mais, mais DDGS (Distiller's Dried Grains with Solubles) en bietenpulp. De prijs wordt 0,89 euro per $100 \mathrm{~kg}$ hoger (3,6\%). Het voer in variant 3 heeft dezelfde samenstelling als dat van variant 2 .

Tabel 5.2 Samenstelling (\% volume) en prijs van A-brok in de basissituatie en bij drie varianten a)

\begin{tabular}{|c|c|c|c|c|}
\hline & Basis & V1 (geen soja) & V2 (EU) & V3 (Europa) \\
\hline Prijs (euro/100 kg) & 24,48 & 24,48 & 25,37 & 25,37 \\
\hline Verschil in prijs (euro/100 kg) & & 0,00 & 0,89 & 0,89 \\
\hline Gerst & 32 & 32 & 0 & 0 \\
\hline Palmpitschilfers & 25 & 25 & $x$ & $\mathrm{x}$ \\
\hline Mais & 11 & 11 & 21 & 21 \\
\hline Mais DDGS & 5 & 5 & 15 & 15 \\
\hline Melasse, biet & 4 & 4 & 4 & 4 \\
\hline Bietenpulp & 0 & 0 & 40 & 40 \\
\hline
\end{tabular}

a) In de tabel staan de belangrijkste grondstoffen; het totaal ervan is circa $95 \%$. 


\section{B-brok}

In deze studie is B-brok een rundveebrok met $17,2 \%$ ruw eiwit. In de basissituatie bevat de B-brok geen soja. Hierdoor is het voer in variant 1 exact gelijk aan de basissituatie (tabel 5.3). In variant 2 is het niet mogelijk palmpitschilfers en zoete lupine te gebruiken. De samenstelling verandert, waarbij een deel van de gerst wordt vervangen door mais DDGS, bietenpulp, raapzaad schilfers en mais, De prijs wordt 1,02 euro per $100 \mathrm{~kg}$ hoger (3,9\%). Het voer in variant 3 is qua samenstelling en prijs gelijk aan variant 2 .

Tabel 5.3 Samenstelling (\% volume) en prijs van B-brok in de basissituatie en bij drie varianten a)

\begin{tabular}{|c|c|c|c|c|}
\hline & Basis & V1 (geen soja) & V2 (EU) & V3 (Europa) \\
\hline Verschil in prijs (euro/100 kg) & & 0,00 & 1,02 & 1,02 \\
\hline Gerst & 40 & 40 & 15 & 15 \\
\hline Palmpitschilfers & 25 & 25 & $x$ & $\mathrm{x}$ \\
\hline Mais DDGS & 9 & 9 & 23 & 23 \\
\hline Bietenpulp & 6 & 6 & 40 & 40 \\
\hline Melasse, biet & 4 & 4 & 4 & 4 \\
\hline Raapzaad schilfers & 0 & 0 & 8 & 8 \\
\hline
\end{tabular}

a) In de tabel staan de belangrijkste grondstoffen; het totaal ervan is circa $95 \%$.

\section{Eiwitrijke brok}

In deze studie heeft een eiwitrijke brok 32,7\% eiwit. In de eiwitrijke brok zit in de basissituatie $37 \%$ sojaschroot (tabel 5.4). De prijs voor de brok is 36,15 euro per $100 \mathrm{~kg}$. In variant 1 wordt het sojaschroot vervangen door onder andere palmpitschilfers en aardappel eiwit. Het voer wordt 3,92 euro per $100 \mathrm{~kg}$ duurder $(+10,8 \%)$. In variant 2 zijn palmpitschilfers en zoete lupine niet toegestaan. Hierdoor wordt $22 \%$ tarwe in het voer opgenomen. De prijsstijging is 4,99 euro per $100 \mathrm{~kg}(+13,8 \%)$. In variant 3 zijn er geen veranderingen ten opzichte van variant 2 .

Tabel 5.4 Samenstelling (\% volume) en prijs van eiwitrijke brok in de basissituatie en bij drie varianten a)

\begin{tabular}{|c|c|c|c|c|}
\hline & Basis & V1 (geen soja) & V2 (EU) & V3 (Europa) \\
\hline Prijs (euro/100 kg) & 36,15 & 40,07 & 41,14 & 41,14 \\
\hline Verschil in prijs (euro/100 kg) & & 3,92 & 4,99 & 4,99 \\
\hline Sojaschroot & 37 & $x$ & $x$ & $x$ \\
\hline Mais DDGS & 25 & 20 & 25 & 25 \\
\hline Palmpitschilfers & 5 & 25 & $x$ & $x$ \\
\hline Raapzaadschilfers & 5 & 0 & 0 & 0 \\
\hline Melasse, biet & 4 & 4 & 4 & 4 \\
\hline Aardappeleiwit & 0 & 15 & 14 & 14 \\
\hline Maisgluten voermeel & 0 & 0 & 2 & 2 \\
\hline
\end{tabular}

a) In de tabel staan de belangrijkste grondstoffen; het totaal ervan is circa $90 \%$. 


\subsection{Varkens}

In de varkenshouderij wordt op de meeste bedrijven alle mengvoer aangekocht. Incidenteel worden er eigen geteelde producten gevoerd aan de varkens. Een deel van de bedrijven past brijvoeders toe, waarbij vochtrijke bijproducten worden gekocht en gevoerd aan de varkens. Van alle varkensvoer is $65 \%$ voer voor vleesvarkens, $22 \%$ is voer voor zeugen (dracht en lacto-voer) en $13 \%$ is biggenvoer. In dit hoofdstuk richten we ons op voer voor vleesvarken, drachtige zeugen en biggen.

\section{Vleesvarkens voer}

Het doorgerekende voer voor vleesvarkens bevat 17,3\% ruw eiwit. In de basissituatie bevat het voer $3 \%$ sojaschroot (tabel 5.5). De prijs is 29,19 euro. Bij variant 1 wordt het sojaschroot vervangen door gerst en lupine. De prijs wordt 0,04 euro per $100 \mathrm{~kg}$ hoger $(+0,1 \%)$. In variant 2 worden naast soja ook lupine en zonnebloemschilfers (uit Oekraïne) uitgesloten. Deze grondstoffen worden vervangen door erwten en zonnebloemschroot. De prijs neemt toe met 0,14 euro per $100 \mathrm{~kg}(+0,5 \%)$. In variant 3 zijn grondstoffen uit Oekraïne mogelijk. Hierdoor worden zonnebloemschilfers in het voer opgenomen, wat de prijs drukt.

Tabel 5.5 Samenstelling (\% volume) en prijs van vleesvarken groei voer in de basissituatie en bij drie varianten a)

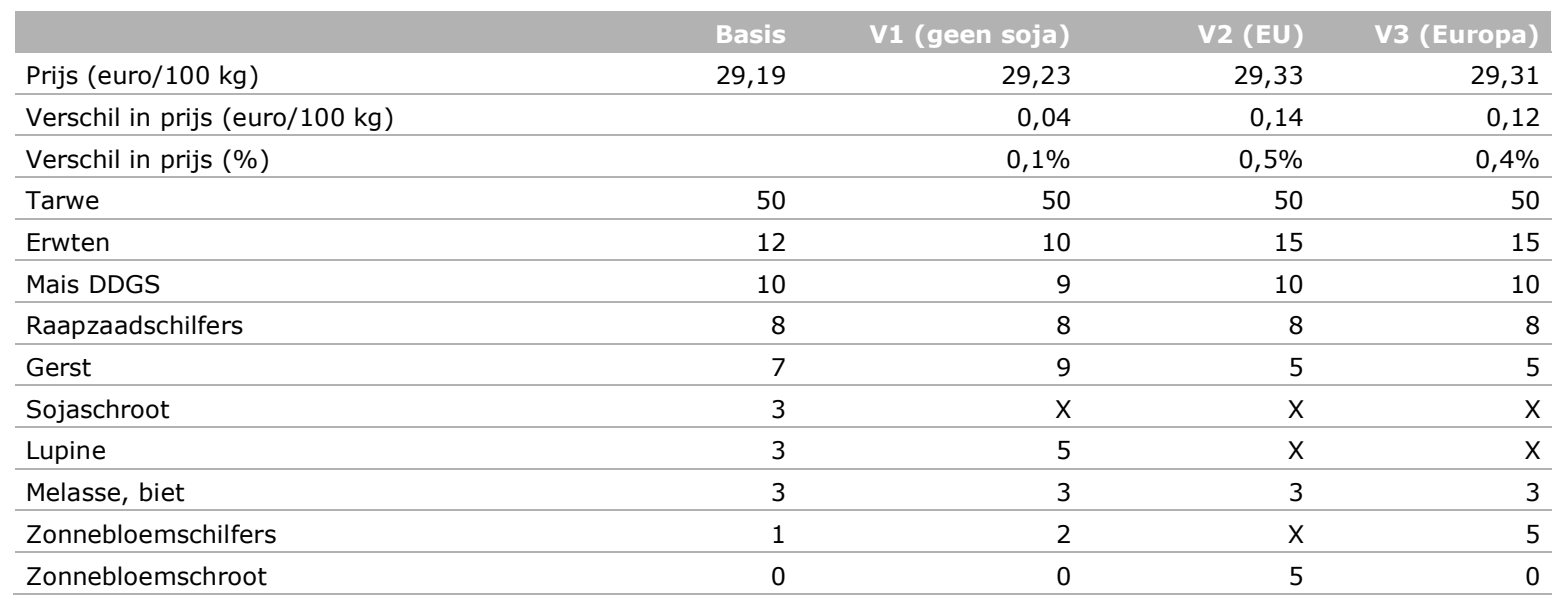

a) In de tabel staan de belangrijkste grondstoffen; het totaal ervan is circa $95 \%$.

\section{Drachtige zeug}

Het doorgerekende voer bevat $11,6 \%$ ruw eiwit. In de basissituatie bevat het voer $15 \%$ soja hullen (tabel 5.6). De prijs is 23,60 euro. Bij variant 1 wordt het soja hullen vervangen door palmpit schroot en bietenpulp. De prijs wordt 0,18 euro per $100 \mathrm{~kg}$ hoger $(+0,8 \%)$. In variant 2 worden naast soja ook palmpitschilfers uitgesloten. Deze grondstoffen worden vervangen door bietenpulp en mais DDGS. De prijs neemt toe met 0,43 euro per $100 \mathrm{~kg}(+1,8 \%)$. In variant 3 is de samenstelling en prijs van het voer gelijk aan variant 2 .

Tabel 5.6 Samenstelling (\% volume) en prijs van voer voor een drachtige zeug in de basissituatie en bij drie varianten a)

\begin{tabular}{|c|c|c|c|c|}
\hline & Basis & V1 (geen soja) & V2 (EU) & V3 (Europa) \\
\hline Prijs (euro/100 kg) & 23,60 & 23,78 & 24,03 & 24,03 \\
\hline Verschil in prijs (euro/100 kg) & & 0,18 & 0,43 & 0,43 \\
\hline Gerst & 46 & 43 & 42 & 42 \\
\hline Tarwegries & 25 & 25 & 25 & 25 \\
\hline Melasse, biet & 3 & 3 & 3 & 3 \\
\hline Bietenpulp & 0 & 14 & 20 & 20 \\
\hline Mais DDGS & 0 & 0 & 6 & 6 \\
\hline
\end{tabular}

a) In de tabel staan de belangrijkste grondstoffen; het totaal ervan is circa $95 \%$. 


\section{Gespeende biggen}

Het doorgerekende voer voor biggen bevat 20,6\% ruw eiwit. In de basissituatie bevat het voer $8 \%$ soja schroot (tabel 5.7). De prijs is 48,78 euro. Bij variant 1 wordt het sojaschroot vervangen door maisglutenmeel en zonnebloem schroot. De prijs wordt 2,23 euro per $100 \mathrm{~kg}$ hoger (4,6\%). In variant 2 worden naast soja ook zonnebloemschilfers (uit Oekraïne) uitgesloten. Deze grondstoffen worden vervangen door zonnebloemschroot uit de EU. De prijs neemt toe met 2,29 euro per $100 \mathrm{~kg}$ $(+4,7 \%)$. In variant 3 wordt de samenstelling en prijs weer gelijk aan variant 1 .

Tabel 5.7 Samenstelling (\% volume) en prijs van voer voor een gespeende biggen in de basissituatie en bij drie varianten a)

\begin{tabular}{|c|c|c|c|c|}
\hline & Basis & V1 (geen soja) & V2 (EU) & V3 (Europa) \\
\hline Prijs (euro/100 kg) & 48,78 & 51,01 & 51,07 & 51,01 \\
\hline Verschil in prijs (euro/100 kg) & & 2,23 & 2,29 & 2,23 \\
\hline Tarwe & 30 & 30 & 30 & 30 \\
\hline Gerst & 25 & 25 & 25 & 25 \\
\hline Sojaschroot & 8 & $x$ & $x$ & $x$ \\
\hline Maisgluten & 5 & 13 & 13 & 13 \\
\hline Aardappeleiwit & 4 & 4 & 4 & 4 \\
\hline Melkpoeder & 3 & 3 & 3 & 3 \\
\hline
\end{tabular}

a) In de tabel staan de belangrijkste grondstoffen; het totaal ervan is circa $90 \%$.

\subsection{Pluimvee}

In de pluimveehouderij wordt op bijna alle bedrijven het voer volledig aangekocht bij een mengvoerfabriek. De pluimveehouderij onderscheidt twee hoofdsectoren, namelijk de vleeskuikenhouderij en de leghennenhouderij. De productie vindt plaats in een productieketen. De opfok van de leghennen vindt veelal plaats op gespecialiseerde opfokbedrijven. In de vleeskuikenhouderij zijn de bedrijven met vleeskuikenouderdieren en de opfok van deze dieren gespecialiseerde bedrijven als voorschakel in de keten. In deze rapportage hebben we voeders doorgerekend voor leghennen (legmeel fase 2), startvoer voor vleeskuikens en groeivoer voor vleeskuikens. Deze sectoren leghennen en vleeskuikens nemen respectievelijk 45 en $40 \%$ van het totale volume in de pluimveesector af.

\section{Vleeskuikens, groeivoer}

Het doorgerekende groeivoer voor vleeskuikens bevat 20,2\% ruw eiwit. In de basissituatie bevat het voer $13 \%$ sojaschroot (tabel 5.8 ). De prijs is 32,81 euro. Bij variant 1 wordt het sojaschroot vervangen door erwten, zonnebloemschroot en aardappeleiwit. De prijs wordt 0,07 euro per $100 \mathrm{~kg}$ hoger $(+0,2 \%)$. In variant 2 worden naast soja ook zonnebloemschroot (37\% eiwit) uit Oekraïne uitgesloten. Deze grondstoffen worden vervangen door mais DDGS en Europees zonnebloemschroot ( $27 \%$ eiwit). De prijs neemt toe met 0,85 euro per $100 \mathrm{~kg}(+2,6 \%)$. In variant 3 worden de Oekraïnegrondstoffen weer opgenomen in het voer. Samenstelling en prijs van het voer is gelijk aan variant 1. 
Tabel 5.8 Samenstelling (\% volume) en prijs van vleeskuiken groeivoer in de basissituatie en bij drie varianten a)

\begin{tabular}{|c|c|c|c|c|}
\hline & Basis & V1 (geen soja) & V2 (EU) & V3 (Europa) \\
\hline Prijs (euro/100 kg) & 32,81 & 32,88 & 33,66 & 32,88 \\
\hline Verschil in prijs (euro/100 kg) & & 0,07 & 0,85 & 0,07 \\
\hline Tarwe & 48 & 43 & 43 & 43 \\
\hline Erwten & 22 & 30 & 30 & 30 \\
\hline Zonnebloemschroot (27\% eiwit) & 0 & 0 & 4 & 0 \\
\hline Raapzaadschilfers & 5 & 5 & 0 & 5 \\
\hline Zonnebloemschroot (37\% eiwit) & 5 & 10 & $x$ & 10 \\
\hline Aardappeleiwit & 1 & 4 & 5 & 4 \\
\hline
\end{tabular}

a) In de tabel staan de belangrijkste grondstoffen; het totaal ervan is circa $90 \%$.

\section{Vleeskuikens, startvoer}

Het doorgerekende startvoer voor vleeskuikens bevat $21,3 \%$ ruw eiwit. In de basissituatie bevat het voer $13 \%$ sojaschroot (tabel 5.9 ). De prijs is 33,48 euro. Bij variant 1 wordt het sojaschroot vervangen door maisglutenmeel, aardappeleiwit en raapzaadschroot. De prijs wordt 1,53 euro per $100 \mathrm{~kg}$ hoger $(+4,6 \%)$. In variant 2 wordt naast soja ook zonnebloemschroot (uit Oekraïne) uitgesloten. Deze grondstoffen worden vervangen door mais DDGS. De prijs neemt toe met 2,26 euro per $100 \mathrm{~kg}(+6,8 \%)$. In variant 3 worden de Oekraïne-grondstoffen weer opgenomen in het voer. De prijsstijging is 1,66 euro per $100 \mathrm{~kg}(+5 \%)$. De prijs is iets lager dan in variant 2 .

Tabel 5.9 Samenstelling (\% volume) en prijs van vleeskuikenstartvoer in de basissituatie en bij drie varianten a)

\begin{tabular}{lrrrr} 
& Basis & V1 (geen soja) & V/2 (EU) & V3 (Europa) \\
Prijs (euro/100 kg) & 33,48 & 35,01 & 35,74 & 35,14 \\
\hline Verschil in prijs (euro/100 kg) & & 1,53 & 2,26 & 1,66 \\
\hline Verschil in prijs (\%) & & $4,6 \%$ & $6,8 \%$ & $5,0 \%$ \\
\hline Tarwe & 41 & 45 & 44 & 43 \\
\hline Erwten & 30 & 30 & 30 & 30 \\
\hline Sojaschroot & 13 & $X$ & $X$ & $X$ \\
\hline Zonnebloemschroot (27\% eiwit) & 0 & 0 & 2 & 0 \\
\hline Raapzaadschilfers & 5 & 0 & 0 & 0 \\
\hline Zonnebloemschroot (37\% eiwit) & 3 & 5 & $X$ & 3 \\
\hline Maisglutenmeel & 0 & 3 & 3 & 3 \\
\hline Aardappeleiwit & 2 & 5 & 5 & 5 \\
\hline Mais DDGS & 0 & 0 & 5 & 5 \\
\hline Raapzaadschroot & 0 & 5 & 5 & 5 \\
\hline
\end{tabular}

a) In de tabel staan de belangrijkste grondstoffen; het totaal ervan is circa $90 \%$.

\section{Leghennen, fase 2 voer}

Het doorgerekende voer voor leghennen bevat 15,5\% ruw eiwit. In de basissituatie bevat het voer $5 \%$ sojaschroot (tabel 5.10). De prijs is 27,32 euro per $100 \mathrm{~kg}$. Bij variant 1 wordt het sojaschroot vervangen door tarwegries, maisglutenmeel, en zonnebloemschroot. De prijs wordt 0,20 euro per $100 \mathrm{~kg}$ hoger $(+0,7 \%)$. In variant 2 worden naast soja ook zonnebloem (37\% eiwit) uit Oekraïne uitgesloten. In het voer komen nu erwten, tarwegries en vooral raapzaadschroot. De prijs neemt toe met 0,46 euro per $100 \mathrm{~kg}(+1,7 \%)$. In variant 3 worden de Oekraïne-grondstoffen weer opgenomen in het voer. Samenstelling en prijs van het voer is exact gelijk aan variant 1. 
Tabel 5.10 Samenstelling (\% volume) en prijs van leghennenvoer (fase 2) in de basissituatie en bij drie varianten a)

\begin{tabular}{|c|c|c|c|c|}
\hline & Basis & V1 (geen soja) & V2 (EU) & V3 (Europa) \\
\hline Prijs (euro/100 kg) & 27,32 & 27,52 & 27,78 & 27,52 \\
\hline Verschil in prijs (euro/100 kg) & & 0,20 & 0,46 & 0,2 \\
\hline Tarwe & 64 & 56 & 53 & 56 \\
\hline Raapzaadschilfers & 14 & 15 & 0 & 15 \\
\hline Sojaschroot & 5 & $\mathrm{x}$ & $x$ & $\mathrm{x}$ \\
\hline Mais DDGS & 5 & 5 & 5 & 5 \\
\hline Erwten & 0 & 0 & 2 & 0 \\
\hline Tarwegries & 0 & 4 & 6 & 4 \\
\hline
\end{tabular}

a) In de tabel staan de belangrijkste grondstoffen; het totaal ervan is circa $95 \%$.

\subsection{Alternatieve eiwitbronnen}

In de berekeningen zijn de huidige beschikbare grondstoffen meegenomen. In de verschillende voeders wordt soja (schroot, olie of hullen) vervangen door vooral raapzaadschroot, zonnebloemschroot of erwten. Daarnaast zijn er andere mogelijkheden om soja te vervangen, namelijk door het gebruik van Europese soja, insecteneiwit of diermeel. In deze paragraaf wordt kort ingegaan op de mogelijkheden van deze alternatieve eiwitbronnen.

\section{Europese soja}

Het aanbod van Europese soja is op dit moment nog zeer beperkt. Europese soja is duurder dan Zuidof Noord-Amerikaanse soja. In de berekeningen die Schothorst Feed Research (SFR) heeft uitgevoerd zijn ook enkele varianten doorgerekend met de mogelijkheid om EU-soja op te nemen in het voer. Hierbij is de prijs van EU sojaschroot 8 euro per $100 \mathrm{~kg}$ hoger dan Amerikaans sojaschroot. Bij deze prijs wordt vooral in eiwitrijke voeders (eiwitrijke rundveebrok, startvoer voor vleeskuikens en biggenvoer) een substantieel deel EU-sojaschroot opgenomen in het voer. Bij de eiwitrijke rundveebrok namelijk 22\% en bij het vleeskuiken startvoer en het biggenvoer circa $8 \%$. Door de duurdere soja stijgt de voerprijs. In de huidige situatie is het vervangen van grote hoeveelheden Amerikaanse soja door EU-soja geen reële mogelijkheid door het zeer beperkte aanbod van EU-soja. Het is ook niet de verwachting dat er op korte of middellange termijn grote hoeveelheden soja geteeld zullen gaan worden in Europa.

\section{Insecten}

In enkele Europese landen worden insecten bedrijfsmatig gekweekt. De productievolumes zijn nog klein maar door de toegenomen vraag neemt de productie wel snel toe. Insecten bestaan uit ingrediënten waarvan eiwitten en olie de meest waardevolle zijn (Hilkens, 2016). Insecteneiwit is uitermate geschikt voor gebruik in veevoer. Maar op dit moment zijn er nog diverse belemmeringen om op grote schaal soja te vervangen door insecteneiwit. Allereerst zijn er juridische barrières omdat volgens de huidige EU-regelgeving het gebruik van insecteneiwit, wat dierlijk eiwit is, in veevoer niet toegestaan is. Overigens is de prijs van insecteneiwit nog zo hoog dat gebruik in veevoer economisch niet aantrekkelijk is. Insectenmeel wordt nu gebruikt in pet food en in visvoer. Ten slotte is de beschikbaarheid van insectenmeel beperkt: de geproduceerde hoeveelheid is een fractie van de grote hoeveelheden soja die gebruikt worden door de Nederlandse veevoersector.

\section{Diermeel}

Diermeel is afkomstig van de verwerking van slachtafvallen. Door het gebruik van diermeel in veevoer worden eiwitrijke dierlijke reststromen benut. Dit past uitermate goed in een kringlooplandbouw. Sinds 2001 (na uitbraken van de 'gekkekoeienziekte') mag in de EU diermeel niet meer gebruikt 
worden in veevoer. Binnen de EU wordt bekeken of gebruik van diermeel van varkens of pluimvee toch mogelijk is. Hierbij wordt gedacht aan toepassing van diermeel van varkens in pluimveevoer en diermeel van pluimvee in varkensvoer. Om een indicatie te krijgen van de effecten heeft SFR ook de optie van diermeel meegenomen in de berekeningen.

Diermeel in varkensvoer

Voor varkensvoer is de mogelijkheid voor opname van diermeel van pluimvee doorgerekend. Pluimveediermeel heeft circa 50\% ruw eiwit en er is gerekend met de prijs van 60 euro per $100 \mathrm{~kg}$. Diermeel van pluimvee is relatief duur omdat dit gebruikt wordt in pet food en ook geëxporteerd wordt naar landen buiten de EU. Ter vergelijking: de prijs voor diermeel van varkens wordt geschat op 35 euro per $100 \mathrm{~kg}$. De genoemde prijzen van diermeel zijn schattingen. In de praktijk zijn er schommelingen in prijs afhankelijk van ontwikkelingen in de afzetmarkt en fluctuaties in wisselkoersen.

In de berekeningen van SFR wordt diermeel van pluimvee niet opgenomen in het voer voor vleesvarken voer. Diermeel van pluimvee wordt pas in het rantsoen opgenomen als de prijs lager is dan 52 euro per $100 \mathrm{~kg}$. Ook in het voer voor drachtige zeugen wordt diermeel van pluimvee niet opgenomen in het voer. Bij het voer voor drachtige zeugen moet de prijs zelfs lager zijn dan 31 euro per $100 \mathrm{~kg}$. In het voer voor gespeende biggen wordt diermeel van pluimvee voor $5 \%$ opgenomen. De prijs van het voer met diermeel is dan 47,93 euro per $100 \mathrm{~kg}$, ofwel 0,85 euro lager dan de prijs van het basisvoer van 48,78 euro per $100 \mathrm{~kg}(-1,7 \%)$.

\section{Diermeel in pluimveevoer}

Door SFR zijn berekeningen gemaakt met de optie om diermeel van varkens op te nemen in pluimveevoer. Varkensdiermeel heeft 50\% ruw eiwit en de prijs waarmee gerekend is 35 euro per $100 \mathrm{~kg}$. Diermeel van varkens is relatief goedkoop omdat het minder afzetmogelijkheden heeft dan diermeel van pluimvee (60 euro per $100 \mathrm{~kg}$ ).

In de berekeningen van SFR wordt diermeel van varkens opgenomen in het pluimveevoer. Per voersoort zijn de resultaten verschillend. In vleeskuikenstartvoer wordt $5 \%$ diermeel opgenomen en het percentage sojaschroot wordt verlaagd van 12,5 naar $8 \%$. Het voer wordt 1,16 euro per $100 \mathrm{~kg}$ $(-3 \%)$ goedkoper. Bij vleeskuikens groeivoer wordt $1 \%$ diermeel opgenomen en daalt de prijs met 0,20 euro per $100 \mathrm{~kg}(-0,6 \%)$. Bij legmeel wordt 4,2\% diermeel opgenomen. Het percentage sojaschroot daalt van 5,3 naar $0 \%$. De prijs van het voer daalt met $1,7 \%$, ofwel met 0,47 euro per $100 \mathrm{~kg}$.

\subsection{Discussie en conclusies}

In de verschillende sectoren zijn er enkele voersoorten met een hoog eiwitgehalte. Voor de rundveehouderij is dit de eiwitrijke brok (gebruikt in een rantsoen met veel snijmais), voer voor biggen in de varkenshouderij en startvoer bij vleeskuikens. Al deze eiwitrijke voeders bevatten relatief veel soja. Volgens de berekeningen wordt in een rantsoen zonder soja deze grondstof vervangen door zonnebloemschroot, raapzaadschroot en erwten en in mindere mate ook mais DDGS, aardappeleiwit, bietenpulp en maisglutenmeel. Tabel 5.11 geeft een overzicht van de belangrijkste resultaten uit dit hoofdstuk. 
Tabel 5.11 Voersoorten met het percentage eiwit en soja en de meerprijs bij de drie varianten: geen soja, EU grondstoffen of Europese grondstoffen

\begin{tabular}{lrrrrr} 
& \multicolumn{5}{c}{ meerprijs voer (\%) } \\
\cline { 2 - 6 } Rundvee & eiwit, \% & soja, \% & V1 (geen soja) & V2 (EU) & V3 (Europa) \\
A-brok & 13,9 & 0 & 0 & 3,6 & 3,6 \\
\hline B-brok & 17,2 & 0 & 0 & 3,9 & 3,9 \\
\hline Eiwitrijk & 32,7 & 37 & 10,8 & 13,8 & 13,8 \\
\hline
\end{tabular}

\begin{tabular}{lrrrrr} 
& \multicolumn{7}{c}{ meerprijs voer (\%) } \\
\cline { 2 - 6 } Varkens & eiwit, \% & soja, \% & V1 (geen soja) & V2 (EU) & V3 (Europa) \\
Vleesvarken & 17,3 & 3 & 0,1 & 0,5 & 0,4 \\
\hline Zeug, drachtig & 11,6 & 15 & 0,8 & 1,8 & 1,8 \\
\hline Biggen & 20,6 & 8 & 4,6 & 4,7 & 4,6 \\
\hline
\end{tabular}

\begin{tabular}{lrrrrr} 
& \multicolumn{7}{c}{ meerprijs voer (\%) } \\
\cline { 2 - 6 } Pluimvee & eiwit, \% & soja, \% & V1 (geen soja) & V2 (EU) & V3 (Europa) \\
Vleeskuiken, groei & 20,2 & 13 & 0,2 & 2,6 & 0,2 \\
\hline Vleeskuiken, start & 21,3 & 13 & 4,6 & 6,8 & 5,0 \\
\hline Legmeel 2 & 15,5 & 5 & 0,7 & 1,7 & 0,7 \\
\hline
\end{tabular}

Bij de variant zonder soja (variant 1 ) blijft bij veel voeders de prijsstijging beperkt tot 0,8\%. Bij de eiwitrijke voerders is de prijsstijging groter: eiwitrijke rundveebrok 10,8\%, startvoer vleeskuikens 4,6 en biggenvoer $4,6 \%$. In vergelijking tot de andere varianten is de prijsstijging beperkt omdat er wereldwijd gekeken kan worden naar alternatieven voor soja.

Bij de variant met EU-grondstoffen (variant 2) is de prijsstijging voor veel voeders 0,5 tot 3,9\%. Bij de eiwitrijke voeders is de prijsstijging groter: eiwitrijke rundveebrok $13,8 \%$, startvoer vleeskuikens 6,8 en biggenvoer $4,7 \%$, Vooral bij de rundvee brok is er een relatief grote stijging bij omschakeling van variant 1 naar variant 2 .

Bij de variant met grondstoffen uit Europa (variant 3) zijn de verschillen met de variant met EUgrondstoffen heel klein. Voor veel voeders is er geen verschil in samenstelling en prijs. Alleen bij de pluimveevoeders is er een duidelijk lagere prijs bij variant 3. Hierbij moet worden aangetekend dat de effecten van deze variant moeilijk te benaderen zijn en vermoedelijk zijn onderschat. 


\section{Gevolgen voor markten en prijzen}

\section{$6.1 \quad$ Inleiding}

Bij de berekening van de kostenstijgingen in het vorige hoofdstuk is uitgegaan van de bestaande prijsverhoudingen van krachtvoergrondstoffen. De daar gevonden prijsstijgingen zijn het gevolg van aanpassingen in de grondstoffenmix waarbij vanwege de geformuleerde kringloopeisen andere grondstoffen moeten worden gebruikt (vergelijk het vervangen van soja), bij gelijkblijvende vraag naar krachtvoer/mengvoer en nutritionele voorwaarden. De vraag is wat er als gevolg van de aanpassing in de grondstoffenmix zal gebeuren met de marktprijzen voor mengvoedergrondstoffen bij diverse kringloopscenario's. Om daar een indicatie van te geven is met behulp van model-analyses nagegaan wat kringloopsluiting op verschillende schalen betekent.

Het gebruikte EDM-model (zie hoofdstuk 2) gaat uit van de eiwitbalansen voor de EU en Nederland zoals die hiervoor zijn besproken (zie hoofdstuk 1 en bijlagen 1 en 2)). Daarmee wordt de grondstoffenkant afgedekt op een zodanige manier dat rekening wordt gehouden met de beschikbaarheid van landbouwgrond om (eventueel andere) gewassen op te telen en met de beschikbaarheid van allerlei bijproducten. Verder houdt het model rekening met de handelsrelaties, die, afhankelijk van het kringloopscenario, eventueel ook kunnen worden 'dichtgezet' (vergelijk een EU-importban op soja). Ten slotte houdt het model rekening met de vraag naar krachtvoeders vanuit de dierlijke sectoren die op haar beurt weer afhangt van de vraag van consumenten naar dierlijke producten.

Met het model zijn de scenario's doorgerekend die kunnen worden gekarakteriseerd als varianten van Europese sluiting van kringlopen (zie paragraaf 2.1).

\subsection{Scenario 'Alleen Nederland beperkt zich tot EU- veevoer'}

Als Nederland geen grondstoffen meer van buiten de EU importeert, zal Nederland proberen om de benodigde veevoergrondstoffen in de rest van de EU aan te kopen. De import uit de rest van de EU zal daardoor fors toenemen $(+377 \%)$. De extra sourcing van Nederland op de EU-27 markt ${ }^{2}$ betekent dat de import van de rest van de EU van buiten de EU met bijna $10 \%$ zal stijgen (tabel 6.1). Dit is een voorbeeld van de bekende driehoeksaanpassing die optreedt bij de instelling van een importban. Hoewel Nederland meer circulair wordt, geldt dit niet voor de rest van de EU. Het saldo van de importreductie van Nederland vanuit de rest van de wereld en de importtoename van de rest van de EU uit de rest van de wereld is negatief: de totale import van de EU-27 uit de rest van de wereld van eiwithoudende grondstoffen neemt af (daling circa 5\%).

Als alleen Nederland zich beperkt tot Europees veevoer, creëert de extra import door Nederland vanuit de rest van de EU extra vraag, die een prijsopdrijvende werking heeft (zie ook figuur 2.1 voor de achtergrond ervan). De prijs stijgt met bijna 4\%. Die prijsstijging is beperkt omdat Nederland ondanks haar intensieve landbouw toch maar een kleine speler is in de grote EU-markt. Bovendien heeft de rest van de EU de vrije optie om meer van buiten de EU te importeren, waardoor de schaarste maar zeer beperkt toeneemt (zie ook de elastische aanbodresponse van de rest van de wereld zoals verantwoord hoofdstuk 2). De Nederlandse keuze leidt er wel toe dat in de hele EU de prijzen omhooggaan (eenheid van markt) en dus zowel in Nederland als in de rest van de EU de krachtvoerkosten oplopen. Dit leidt tot een kleine uitbreiding van de eigen productie van de EU van

\footnotetext{
2 De EU-27 verwijst hier naar de EU-28 (inclusief het VK) minus Nederland. Omdat in de EU eiwitbalans het VK als lidstaat van de EU is meegenomen is vanuit pragmatische redenen dit aggregatieniveau gekozen.
} 
veevoer ( +400.000 ton eiwitrijk veevoer) en een verwaarloosbare krimp in de vraag naar veevoer $(-0,2 \%)$ EU-breed.

Tabel 6.1 Resultaat scenario 'Alleen NL beperkt zich tot EU veevoer' (in \% veranderingen ten opzichte van baseline)

\begin{tabular}{|c|c|c|c|}
\hline & Nederland & Rest van de EU & EU-27 \\
\hline Verbruik eiwitrijk veevoer & $-0,2$ & $-0,2$ & $-0,2$ \\
\hline \multicolumn{4}{|c|}{ Aanvoer eiwitrijk veevoer, waarvan, } \\
\hline import van buiten EU & $-99,9$ & 9,9 & $-5,6$ \\
\hline import vanuit de EU & 376,8 & & \\
\hline
\end{tabular}

De prijsstijgingen voor eiwitrijk veevoer (oliezaadschroot (raapzaad en zonnebloem) en overige eiwithoudende gewassen) werken door in de mengvoerprijzen. Voer voor vleesvarkens en vleeskuikens heeft circa $25 \%$ eiwitrijke grondstoffen. Bij een prijsstijging van circa $4 \%$ van de eiwitrijke grondstoffen wordt het voer dan $1 \%$ duurder. Bij variant V2 (geen import van buiten de EU) betekent dit voor vleesvarkensvoer een prijsstijging van $1,5 \%$ (in plaats van $0,5 \%$ ) en voor vleeskuikens groei voer een prijsstijging van 3,6\% (in plaats van $2,6 \%$ ). Eiwitrijke rundveebrok heeft circa $50 \%$ eiwitrijke grondstoffen. Dan is de extra prijsstijging $2 \%$. Bij uitsluiting van alle grondstoffen die de EU importeert uit derde landen is de totale prijsstijging voor eiwitrijke brok dan 15,8\% (in plaats van $13,8 \%)$.

\subsection{Scenario 'EU-27 beperkt zich tot EU-27 veevoer'}

In dit scenario importeert Nederland geen grondstoffen van buiten de EU en doen de andere lidstaten dat ook niet. De impact daarvan wordt in twee stappen uitgelegd: eerst het kortetermijneffect, bij ongewijzigde productiecapaciteit van de dierlijke sectoren. Daarna als tweede stap de middellange termijn, waarin de omvang van de dierlijke sectoren verder wordt aangepast.

De EU-afhankelijkheid van de rest van de wereld voor plantaardig eiwit kwam al eerder aan de orde (hoofdstuk 1). Nu alle EU-27 import naar nul moet ontstaat er grote schaarste en de prijs voor eiwitrijk veevoer schiet met $91 \%$ omhoog (bijna een verdubbeling). Nederland zal proberen om de benodigde veevoergrondstoffen nu in de rest van de EU aan te kopen. De binnenlandse productie in de EU is prijsinelastisch, maar laat bij deze extreme prijsstijging toch een toename van de eigen productie van eiwitrijk veevoer van circa $10 \%$ zien. Ondanks de grote schaarste die nu overal in de EU heerst, betrekt Nederland toch nog krachtvoerimporten uit de rest van de EU (fors meer dan in de baseline, maar minder dan in het scenario 'Alleen NL beperkt zich tot EU veevoer'.

Tabel 6.2 Resultaat scenario 'Alle EU-27 lidstaten beperken zich tot EU-veevoer' (in \% veranderingen ten opzichte van baseline): kortetermijneffect

\begin{tabular}{|c|c|c|c|}
\hline & Nederland & Rest van de EU & EU-27 \\
\hline Verbruik eiwitrijk veevoer & $-3,2$ & $-3,2$ & $-3,2$ \\
\hline \multicolumn{4}{|l|}{ Aanvoer eiwitrijk veevoer } \\
\hline import van buiten EU & $-93,5$ & $-99,9$ & $-99,0$ \\
\hline import vanuit de EU & 272,0 & & \\
\hline
\end{tabular}

Merk op dat er in eerste instantie (tabel 6.2) van wordt uitgegaan dat de veehouderijsectoren via hun 'normale vraagcurve' zullen reageren (kortetermijnreactie waarbij de fixed assets (de 
productiecapaciteit) vastliggen). Dit is echter geen houdbare situatie. Bij eiwitprijsstijgingen van $90 \%$ zijn de dierlijke sectoren in de EU niet langer competitief ten opzichte van derde landen. Naar verwachting zal er een grote import van elders geproduceerde (goedkopere) dierlijke producten (zuivel, vlees, eieren) op gang komen om aan de consumentenvraag te voldoen. Ergens zal zich dan een nieuw evenwicht instellen, waarbij er kleinere maar efficiëntere dierlijke sectoren (met technische aanpassingen conform de dan geldende prijsverhoudingen) overblijven en de eiwitprijsstijging binnen meer normale proporties blijft (zeg structureel maximaal $10-15 \%$ boven de prijs in de baseline). Op basis van simulaties met het model kan indicaties worden verkregen hoe dit nieuwe middellangetermijn-evenwicht eruit zou kunnen zien. Resultaten zijn weergegeven in tabel 6.3. Gemiddeld zal de vraag naar eiwitrijkvoer dan structureel met circa $10 \%$ moeten verminderen. Dit betekent een gemiddelde krimp van de dierlijke sectoren van ook ongeveer $10 \%$, waarbij het overigens mag worden verwacht dat de grondgebonden dierlijke producties (zuivel, rundvlees, schapen) relatief minder zullen krimpen en intensieve niet-grondgebonden dierlijke producties sterker dan het gemiddelde. Dit komt door het lagere aandeel van aangekocht veevoer in de totale productiekosten van de grondgebonden dierlijke producties. Nederland blijft dan nog steeds veevoer van buiten importeren. In het geval van autarkie (zie hoofdstuk 4) zou de krimp van de Nederlandse veestapel veel sterker moeten zijn.

Tabel 6.3 Resultaat scenario 'Alle EU-27 lidstaten beperken zich tot EU-veevoer' (in \% veranderingen ten opzichte van baseline): middellangetermijneffect

\begin{tabular}{|c|c|c|c|}
\hline & Nederland & Rest van de EU & EU-27 \\
\hline Verbruik eiwitrijk veevoer & $-10,5$ & $-10,5$ & $-10,5$ \\
\hline \multicolumn{4}{|l|}{ Aanvoer eiwitrijk veevoer } \\
\hline import van buiten EU & $-100,0$ & $-100,0$ & $-100,0$ \\
\hline import vanuit de EU & 247,6 & & \\
\hline
\end{tabular}

\subsection{Scenario 'Nederland en Duitsland beperken zich tot EU-veevoer'}

Het is denkbaar dat naast Nederland ook Duitsland zich beperkt tot uitsluitend aankoop van veevoer dat binnen de EU is geteeld. Dit scenario kan niet separaat worden doorgerekend omdat Duitsland in het model onderdeel is van de rest van de EU. Gegeven de resultaten van het scenario 'Alleen NL beperkt zich tot EU veevoer' kan wel een kwalitatieve inschatting van de impact van een dergelijk scenario worden gemaakt. Duitsland is een veel groter land dan Nederland, met ook in absolute omvang een grote landbouwsector. Echter in haar afhankelijkheid van eiwitimporten van buiten de EU (vergelijk sojabonen en soja schroot importen) is het land redelijk vergelijkbaar met Nederland. Het land heeft bovendien een grote eigen veevoerproductie.

Als Duitsland zich ook zou beperken tot EU veevoer mag worden verwacht dat er een vergelijkbare reactie in de markten zal ontstaan als eerder bij het scenario 'Alleen NL beperkt zich tot EU veevoer' is getoond. Door het verschil in omvang zal de schaarste op de EU-binnenmarkt evenwel naar verwachting wat sterker toenemen dan in het scenario 'Alleen NL beperkt zich tot EU veevoer'. Tegelijkertijd blijft het mechanisme van de driehoeksaanpassing voor de rest van de EU open. De importstromen van buiten de EU zullen zich gaan verleggen van Nederland en Duitsland naar andere EU-lidstaten. Dat creëert dan voor hen ruimte om een deel van hun veevoerproductie te exporteren naar Nederland en Duitsland om aan hun vraag te voldoen.

Dit zal de prijs van eiwitrijk veevoer in de hele EU doen stijgen, maar een structurele stijging van meer dan $10 \%$ lijkt hierbij niet waarschijnlijk. Dit komt omdat de prijselasticiteit van het aanbod van eitwitrijke veevoergrondstoffen vanuit de rest van de wereld naar de EU hoog is. Een stijging van de eiwitprijs in de EU zal daardoor gemakkelijk extra aanvoer van elders creëren. Een praktisch issue is 
wel dat Nederland en Duitsland een goede infrastructuur hebben voor de aanvoer van

veevoergrondstoffen van buiten de EU (diepzeehavens), terwijl alternatieve kanalen wat infrastructuur betreft mogelijk nog verdere ontwikkeling en investeringen vragen. Die laatste logistieke aspecten kunnen niet in de model-analyse worden meegenomen, maar zouden ertoe kunnen leiden dat er lokale prijsverschillen/stijgingen ontstaan die sterker zijn dan het algemene patroon en relatief negatief uitwerken voor de concurrentiepositie van Nederland en Duistland.

\subsection{Scenario 'Veevoer uit Oekraïne is toegestaan'}

De grens van Europa wordt in dit scenario breder getrokken dan de EU. Bij de sluiting van kringlopen worden importen van eiwitrijke veevoergrondstoffen vanuit Oekraïne als 'interne importen' opgevat die ook onder het kringloopbeleid toegestaan zijn. Oekraïne is een belangrijk landbouwland en produceert nu al grote hoeveelheden eiwithoudende veevoergrondstoffen, waarvan ook aanzienlijke hoeveelheden worden geëxporteerd (zie tabel 6.4). Bovendien is er potentie tot verdere ontwikkeling van de productie van eiwitrijke veevoergrondstoffen.

Tabel 6.4 Productie en export van Oekraïne van oliehoudende zaden (in $\mathrm{mln}$. ton)

\begin{tabular}{lcc} 
Product & Binnenlandse productie & \\
Sojabonen & 3,9 & 2,2 \\
\hline Raapzaad & 1,7 & 1,4 \\
\hline Zonnebloemzaad & 11,2 & 0,7 \\
\hline Totaal & 17,8 & 4,3 \\
\hline
\end{tabular}

Bron: Agmemod-database (deels geschat, informatie voor 2015 of het dichtst mogelijke jaar waarvoor informatie beschikbaar is).

De export van oliezaden door Oekraïne is vergelijkbaar met de totale netto-import van Nederland (zie eiwitbalans van Nederland (bijlage 2) met een netto-import van 4,3 miljoen ton). In theorie zou Oekraïne het gat dat ontstaat doordat Nederland niet meer van buiten de EU importeert precies kunnen opvullen. Het rekenen met de EU inclusief Oekraïne biedt daarom verdere sourcingmogelijkheden, zowel voor Nederland als de rest van de EU. De prijsstijgende werking zoals bij de eerder besproken scenario's zal daardoor bij een EU inclusief Oekraïne worden gedempt.

In het scenario 'Alle EU-27 lidstaten beperken zich tot EU-veevoer' moet rekening worden gehouden met een forse prijsstijging van eiwitrijke veevoergrondstoffen, ook als met de EU inclusief Oekraïne wordt gewerkt. Gezien ten opzichte van het totaal van het eiwittekort van de EU-27, biedt Oekraïne wel verlichting, maar is ze zeker geen voldoende vervanging voor wat nu van elders wordt geïmporteerd (zie eiwitbalans van de EU in bijlage 1).

\subsection{Reflectie}

Er zijn hierboven twee scenario's kwantitatief doorgerekend en twee scenario's kwalitatief geanalyseerd. De gepresenteerde kwantitatieve berekeningen zijn indicatief omdat ze met een relatief eenvoudig EDM-model zijn doorgerekend. Bovendien ligt de focus op de eiwitkant en is de energiekant niet expliciet in de beschouwing betrokken. De EU is in principe meer dan zelfvoorzienend wat betreft energiehoudende veevoergrondstoffen. Als de EU substantieel meer eiwithoudende gewassen zou gaan telen, kan daar overigens wel verandering in komen.

In het scenario 'Alleen NL beperkt zich tot EU veevoer' mag een gemiddelde eiwitprijsstijging van enkele procenten (circa 4\%) worden verwacht. Dit betekent dat de prijsstijging van 'circulair veevoer' hoger uitkomt dan de percentages genoemd in tabel 5.11 (zie ook paragraaf 5.6). Daar werd verondersteld dat de mix van grondstoffen wel kan veranderen, maar de prijzen constant blijven. De beperkte prijsstijging zal zich door de marktwerking (arbitrage) EU-breed voordoen. De impact op de relatieve concurrentieposities kan daardoor beperkt blijven, hoewel het voor de hand ligt dat er zich 
lokaal van dit gemiddelde afwijkende prijsstijgingen kunnen voordoen die de concurrentie positie van Nederland ('Alleen NL beperkt zich tot EU veevoer'-scenario), of die van Nederland en Duitsland ('NL en DLD beperken zich tot EU-veevoer'-scenario) negatief beïnvloeden.

Als alleen Nederland een kringloopbeleid met betrekking tot veevoer gaat volgen, zal de krimp van de dierlijke sectoren beperkt blijven (geringe prijsstijging eiwitrijke veevoergrondstoffen). Maar de uitkomst ervan zal zijn dat de nettopositie van de EU weinig verandert: wat Nederland minder van buiten de EU importeert wordt voor het grootste deel extra geïmporteerd door de overige landen in de EU-27. Wanneer ook Duitsland mee zou doen in het kringloopbeleid met veevoergrondstoffen zal dat beeld naar verwachting weinig veranderen. Wanneer Nederland zou besluiten om niet meer van buiten de EU (met name soja uit Noord- en Zuid Amerika) te importeren, maar dat compenseert met extra importen uit Oekraïne, dan voldoet dat misschien aan een (politieke) 'inclusieve EU-kringloopdefinitie', maar met echte kringlooplandbouw heeft dat weinig te maken.

Een aspect dat nog niet is benoemd, maar wel cruciaal is voor een meer compleet verhaal over kringlooplandbouw, zijn de gevolgen van de scenario's voor de markt voor eindproducten van de dierlijke sectoren. Wanneer zoals bij het scenario 'Alle EU-27 lidstaten beperken zich tot EU-veevoer' de krachtvoerprijzen fors zouden gaan stijgen, verandert ook de concurrentiepositie van de dierlijke sectoren in de EU ten opzichte van die buiten de EU. Dat zou tot grote importen van dierlijke producten (zuivel, vlees, eieren) kunnen leiden, zeker als de EU geen grensmaatregelen zou nemen om een gelijk speelveld te realiseren. Gebeurt dat niet, dan hebben bedrijven in de EU niet of nauwelijks de mogelijkheid om de (extra) kosten door te berekenen aan de eindgebruiker. Dit zou zeker voor het 'extreme' scenario 'Alle EU-27 lidstaten beperken zich tot EU-veevoer' het einde betekenen van veel bedrijven en ook van daarmee samenhangende toeleverende en verwerkende industrie. De EU noemt in haar beleidsstukken wel het belang van een gelijk speelveld en de mogelijkheid van corrigerende grensmaatregelen, maar een dergelijke 'bescherming' is erg onwaarschijnlijk als een of enkele lidstaten hun landbouw volgens de besproken scenario's meer circulair willen maken. Overigens is het denkbaar dat de consumententrend van een afnemend verbruik van dierlijke producten, die nu nog zeer bescheiden is, door de prijsstijgingen zal worden versterkt. Ook dit effect is niet meegenomen (en moeilijk in te schatten).

In het geval van een (forse) krimp van de landbouw in Nederland en/of de EU zullen ook de milieueffecten (emissies van ammoniak en broeikasgassen) van de landbouw veranderen. Ook de beschikbaarheid en aanwending van organische mest veranderen en daarmee samenhangend ook het gebruik van kunstmest. De gevolgen en de waardering daarvan (bijvoorbeeld in de vorm van vermeden milieukosten) zijn in deze studie niet uitgewerkt, maar wel neveneffecten van dergelijke scenario's. 


\section{$7 \quad$ Slotbeschouwingen}

\section{Eiwitvoorziening als sleutelfactor}

In hoofdstuk 1 is vastgesteld dat de eiwitvoorziening de sleutelfactor is bij het sluiten van de voermestkringloop. Voor wat betreft de energiekant van het veevoer is de EU netto-exporterend. Daarentegen is de EU al decennia een belangrijk tekortgebied voor plantaardig eiwit. Dit tekort wordt grotendeels gedekt door soja uit Noord- en Zuid-Amerika. De trend om minder dierlijke producten te verbruiken zal voorlopig geen verandering in deze structurele situatie brengen.

\section{Beperkte veranderingen bij ongewijzigd beleid}

Het referentiescenario (hoofdstuk 3) laat beperkte veranderingen in de dierlijke productie van de EU zien. In Nederland zal de veestapel naar verwachting licht krimpen. De productiviteit van de koeien stijgt, maar de melkproductie blijft stabiel omdat fosfaatrechten uit de markt worden gehaald als gevolg van opkoopregelingen in het stikstofbeleid. Het aantal varkens in Nederland zal afnemen als gevolg van de Saneringsregeling Varkenshouderij. De productie van pluimveevlees in de EU groeit volgens de vooruitzichten de komende jaren door. In Nederland is uitbreiding van de pluimveestapel echter niet mogelijk door het stelsel van pluimveerechten. Voor de gehele veestapel zal eiwitrijk voer een belangrijk deel uit blijven maken van het voerrantsoen. Volgens de vooruitblik zal de EU in 2030 ongeveer $57 \mathrm{mln}$. ton eiwitrijk voer in de veehouderij verbruiken. Sojaschroot zal naar verwachting het meeste worden toegepast als voer. Dit kan oplopen tot $31 \mathrm{mln}$. ton.

\section{Extreme krimp veehouderij bij alleen Nederlands veevoer}

Het Nederland-autarkie-scenario ('alleen Nederlands veevoer') gaat gepaard met een extreme krimp van de veehouderijsectoren, variërend van 30\% (melkvee) tot $90 \%$ (kippen). Dit scenario (hoofdstuk 4) is niet tot in detail doorgerekend mede omdat er vanwege het extreme karakter nogal wat aannamen zouden moeten worden gemaakt. Nederland is onderdeel van de interne market van de EU en kan alleen daarom al niet een importbelemmeringsmuur om de nationale grens optrekken. De implicaties in de consumptiesfeer (of het consumptiepatroon 'gedwongen' aanpassen, of de import van dierlijke (eind)producten accepteren) zijn niet nader geanalyseerd, maar kunnen ook ingrijpend zijn.

\section{Kostenverhogingen door kringloopeisen ...}

Zoals uit hoofdstuk 5 bleek is aanpassing van het Nederlandse veevoer aan kringloopeisen met betrekking tot alleen Nederland (de beide scenario's 'geen soja' in mengvoer en 'alleen gebruik van Europese grondstoffen') mogelijk. Deze scenario's leiden tot prijsstijgingen van krachtvoer die afhankelijk van het scenario variëren van $0 \%$ tot $14 \%$ (eiwitrijke rundveekrachtvoerbrok). In veel gevallen kunnen de prijsstijgingen beperkt blijven tot $5 \%$. Hierbij is uitgegaan van de huidige prijsverhoudingen.

... en door toenemende schaarste ...

Als Nederland meer grondstoffen binnen de EU of Europa gaat betrekken, zal dit leiden tot extra prijsstijgingen voor oliezaadschroot (raapzaad en zonnebloem) en overige eiwithoudende gewassen (hoofdstuk 6). Voer voor vleesvarkens en vleeskuikens heeft circa $25 \%$ eiwitrijke grondstoffen. Bij een prijsstijging van $4 \%$ van de eiwitrijke grondstoffen wordt het voer dan $1 \%$ duurder. Bij variant V2 (geen import van buiten de EU) betekent dit voor vleesvarkensvoer een prijsstijging van 1,5\% (in plaats van $0,5 \%$ ) en voor vleeskuikens groei voer een prijsstijging van 3,6\% (in plaats van $2,6 \%$ ). Eiwitrijke rundveebrok heeft circa $50 \%$ eiwitrijke grondstoffen. Dan is de extra prijsstijging $2 \%$. Bij uitsluiting van alle grondstoffen die de EU importeert uit derde landen (V2) is de totale prijsstijging voor eiwitrijke brok dan $15,8 \%$ (in plaats van $13,8 \%$ ).

\section{... en met een grote invloed op het inkomen}

$\mathrm{Bij}$ het gebruiken van 'circulair veevoer' worden de veehouders geconfronteerd met een stijging van de voerprijzen. Een prijsstijging van $1 \%$ voor bijvoorbeeld voer van vleesvarkens lijkt weinig, maar geeft een forse kostenstijging van de voerkosten. In een situatie dat de veehouder bij het gebruiken 
van 'circulair veevoer' geen hogere opbrengstprijs krijgt voor de producten (melk, vlees of eieren), daalt het inkomen fors. Voor de variant met uitsluitend EU-veevoergrondstoffen (V2) is het effect op het inkomen voor een vleeskuikenhouder meer dan 30.000 euro, voor een vleesvarkenhouder 13.000 euro en voor een melkveehouder (met een snijmais rantsoen) circa 10.000 euro.

\section{Alternatieve eiwitbronnen}

In de voeders kan eiwit ook vervangen worden door alternatieve eiwitbronnen. In dit kader worden genoemd Europese soja, insecteneiwit en diermeel. Elk alternatief heeft zijn specifieke beperkingen en geeft geen directe oplossing voor vervanging van bijvoorbeeld soja uit derde landen. In de huidige situatie is het vervangen van grote hoeveelheden Amerikaanse soja door EU soja geen reële mogelijkheid door het zeer beperkte aanbod van EU-soja. Het is ook niet de verwachting dat er op korte of middellange termijn grote hoeveelheden soja geteeld zullen gaan worden in Europa. In steeds meer landen worden bedrijfsmatig insecten gekweekt. Op dit moment zijn er juridische barrières om insecteneiwit te gebruiken in diervoer. Ook is de prijs nog te hoog voor toepassing in voer voor landbouw huisdieren. Het gebruik van diermeel biedt wel perspectief op korte en middellange termijn. Vooral diermeel van varkens gebruikt in vleeskuikenvoer geeft een hoogwaardig voer voor een lagere prijs. Doordat het gebruik van diermeel niet is toegestaan moeten eerst juridische belemmeringen op EU niveau worden weggenomen.

\section{Intensieve veehouderijcomplex gevoeliger dan grondgebonden veehouderijcomplex}

De eventuele krimp en kostenverhogingen in de primaire sectoren werken door in de andere schakels van het veehouderijcomplex. Door de grote importafhankelijkheid van eiwitrijke grondstoffen is het intensieve veehouderijcomplex gevoeliger dan het grondgebonden veehouderijcomplex. Varkens en pluimvee zijn immers hoofdzakelijk aangewezen op krachtvoeders. Melkkoeien zijn herkauwers, die een groot deel van hun eiwitbehoefte betrekken uit ruwvoer.

\section{Zorgen over gelijk speelveld}

In het scenario 'Alle EU-27 lidstaten beperken zich tot EU-veevoer' lopen de krachtvoerprijzen fors op. Hierdoor verandert ook de concurrentiepositie van de dierlijke sectoren in de EU ten opzichte van die buiten de EU. Dat kan tot grote importen van dierlijke producten (zuivel, vlees, eieren) leiden, zeker als de EU geen compenserende maatregelen zou nemen om een gelijk speelveld te realiseren. Gebeurt dat niet, dan hebben bedrijven in de EU niet of nauwelijks de mogelijkheid om de (extra) kosten door te berekenen aan de eindgebruiker.

\section{Milieueffecten ongewis}

De gedachte dat minder import van soja, palmproducten en andere veevoercomponenten uit andere continenten zal leiden tot minder uitstoot van broeikasgassen (en minder ontbossing en biodiversiteitsverlies) in de gebieden waar veevoer vandaan komt moet genuanceerd worden. Dit mag zo zijn door de inkrimping van de veestapel die in Nederland (of Europa) plaatsvindt, maar de uiteindelijke gevolgen van een dergelijke ontwikkeling in Nederland/Europa hangen af van de vraag hoe de veehouderijsectoren in andere landen hierop reageren. Als andere landen in het gat springen dat Nederland en EU op de afzetmarkten voor zuivel en vlees laten vallen, is het effect waarschijnlijk nihil. De EU melkveehouderij is bijvoorbeeld relatief efficiënt (lage broeikasgasemissie per kilogram product) ten opzichte van die van buiten de EU. Afname van of zelfs een verbod op de invoer van veevoer uit andere streken kan wel belangrijke lokale milieueffecten hebben, als lokale mineralenoverschotten ermee worden verminderd.

\section{Alternatieve instrumenten effectiever}

Invoerbeperkingen laten zich lastig regelen. Afspraken over de gemeenschappelijke markt van de EU en over internationale handel in WTO-verband verhinderen dergelijke overheidsmaatregelen.

Aanwendingsnormen op het gebied van mest en dierrechten zijn effectiever om het milieu te ontzien. Op dat terrein liggen meer mogelijkheden voor nationaal beleid.

\section{Geen draagvlak voor EU-brede importstop}

Gegeven dat de EU een tekortgebied is voor plantaardig eiwit zal import van plantaardig eiwit nodig blijven om min of meer zelfvoorzienend te kunnen zijn met betrekking tot dierlijke producten (zuivel, vlees en eieren). Het lijkt daarom onwaarschijnlijk dat lidstaten een kringloopidee zullen gaan 
omarmen waarbij de import van soja wordt uitgesloten. Het is niet alleen de Wereldhandelsorganisatie die dit problematisch maakt (de EU zal als er al met zoiets wordt ingestemd met forse compensatiebedragen over de brug moeten komen), maar ook de ermee verbonden krimp van veehouderijsectoren en hun verlies aan concurrentievermogen (met als alternatief importen van dierlijke eindproducten van buiten de EU om in de consumentenvraag te voorzien) die dit onwaarschijnlijk maakt (hoofdstuk 6). 


\section{Literatuur en websites}

Agrimatie: www.agrimatie.nl

Berkum, S. van en P. Berkhout, Handel en circulariteit: consequenties van kringlooplandbouw voor handel, In: Dolman, M.A, G.D. Jukema, P. Ramaekers (red.), 2019. De Nederlandse landbouwexport in 2018 in breder perspectief. Wageningen Economic Research, Rapport 2019-001.

Beldman, A., J. Reijs, C. Daatselaar en G. Doornewaard, 2020. De Nederlandse melkveehouderij in 2030; Verkenning van mogelijke ontwikkelingen op basis van economische modellering. Wageningen Economic Research, Rapport 2020-090.

Boer, I.J.M. de en M.K. van Ittersum, 2018. Circularity in agricultural production. Wageningen, WUR (achtergrond publicatie bij Mansholtlezing, 2018). https://research.wur. nl/en/publications/circularityin-agricultural-production (retrieved: 2020-03-29)

Bremmer, B., O.N.M. van Eijk, T. Vellinga T, C. te Pas, J. Scholten, B.G. Meerburg en C. Verburg, 2021. Kringloopeffecten van het stoppen van import van diervoedergrondstoffen van buiten de EU; Verkenning met behulp van de KringloopToets. Wageningen Livestock Research, Openbaar Rapport 1299.

Bruggen, C. van en M. Gosseling, 2019. Dierlijke mest en mineralen, 1990-2018. CBS, 2019.

CLO, 2020. Compendium voor de Leefomgeving. Natuurlijke hulpbronnen, indicator landvoetafdruk 1990-2017. https://www.clo.nl/indicatoren/nl0075-voetafdruk-landgebruik. Update 16 april 2020.

Daatselaar, C. Expert melkveehouderij. Persoonlijke mededeling. Augustus 2020.

EC, 2019. EU agricultural outlook for markets and income, 2019-2030. European Commission, DG Agriculture and Rural Development, Brussels.

EC, 2020a. Middellange termijn: een vooruitblik op de middellange termijn voor landbouwmarkten en -inkomens. Europese Commissie, Brussel. https://ec.europa.eu/info/food-farmingfisheries/farming/facts-and-figures/markets/outlook/medium-term_nl (retrieved: 2020-10-20).

EC, 2020b. EU + UK Feed Protein Balance Sheet 2018/19.

https://ec.europa.eu/info/news/commission-publishes-eu-feed-protein-balance-sheet-2019-202020-jul-01_en

Feedprint, versie Juni 2020. https://www.wur.nl/nl/show/FeedPrint-Bereken-de-hoeveelheid-CO2-perkilogram-vlees-melk-of-eieren.htm

FEFAC: https://fefac.eu/wp-content/uploads/2021/02/FF_2020_Final.pdf

Harrington, D. en R.S. Dubman, 2018. Equilibrium Displacement Mathematical Programming Models: Methodology and Model of the U.S. Agricultural Sector. Ers.usda.gov.

Hilkens, W., 2016. Insectenkweek: kleine sector, grote kansen. Rapport van ABNAMRO en de Brabantse Ontwikkelings Maatschappij. Insights.abnamro.nl, December 2016.

Horne, P. van. Persoonlijke mededeling Expert pluimveehouderij.

Hoste, R. Expert varkenshouderij. Persoonlijke mededeling. Augustus 2020. 
IDH, 2020. European Soy Monitor, Insights on European responsible and deforestation-free soy consumption in 2018. https://www.idhsustainabletrade.com/uploaded/2020/05/IDH-EuropeanSoy-Monitor-v2.pdf

Jongeneel, R. en A.R. Gonzalez-Martinez, 2020. Estimating crop yield supply responses to be used for market outlook models: Application to major developed and developing countries. NJAS Wageningen Journal of Life Sciences, 92, [100327]. https://doi.org/10.1016/j.njas.2020.100327.

Krimpen, M.M. van en A. Cormont, 2019. Het percentage regionaal eiwit in het Nederlandse mengvoer; actualisatie voor 2018. Wageningen Livestock Research, the Netherlands (WLR), Wageningen University \& Research, WLR rapport 1222.

Lesschen, J.P., J.W. Reijs, Th.V. Vellinga, J. Verhagen, H. Kros, M. de Vries, R.A. Jongeneel, Th. Slier, A. Gonzalez Martinez, I. Vermeij en C.H.G. Daatselaar, 2020. Scenariostudie perspectief voor ontwikkelrichtingen Nederlandse landbouw in 2050. Rapport Wageningen Environmental Research 2984.

PBL, 2012. De Nederlandse voetafdruk op de wereld: Hoe groot en hoe diep? Augustus 2012.

https://www.pbl.nl/sites/default/files/downloads/PBL_2012_De_Nederlandse_voetafdruk_5004110 02.pdf

Terluin, I., B., Kamphuis, D. Oudendag en M. van Leeuwen, 2013. Voedselvoorziening in Nederland onder buitengewone crisisomstandigheden. LEI rapport 2013-012, Den Haag. Februari 2013.

Velthof, G. L., C. van Bruggen, E. Arets, C.M. Groenestein, J.F.M. Helming, H.H. Luesink, M.J. Schelhaas, J.F.M. Huijsmans, L.A. Lagerwerf en J. Vonk, 2019. Referentieraming van emissies naar de lucht uit landbouw en landgebruik tot 2030: Achtergronddocument bij de Klimaat-en Energieverkenning 2019, met ramingen van emissies van methaan, lachgas, ammoniak, stikstofoxide, fijnstof en NMVOS uit de landbouw en kooldioxide en lachgas door landgebruik, Wageningen: Wageningen Environmental Research. 113 p. (Wageningen Environmental Research rapport; no. 2970)

Wolf, P. de, D. Verstand, K.J. Poppe en Th.V. Vellinga, 2019. Mest en Metropolen: een bijdrage aan de discussie over oplossingsrichtingen voor het sluiten van kringlopen. Wageningen UR, rapport 791. Lelystad, mei 2019. 


\section{Bijlage 1 Eiwitbalans EU}

Tabel B1.1 Eiwitbalans op EU-niveau, 2018

\begin{tabular}{|c|c|c|c|c|c|c|c|c|c|}
\hline Crop/product (million tons) & production & imports & exports & $\begin{array}{l}\text { net } \\
\text { imports }\end{array}$ & $\begin{array}{l}\text { total } \\
\text { domestic } \\
\text { use }\end{array}$ & feed use & $\begin{array}{l}\text { protein } \\
\text { content } \\
\text { (feed use) }\end{array}$ & $\begin{array}{l}\text { Total feed } \\
\text { used (crude } \\
\text { prot) }\end{array}$ & $\begin{array}{l}\% \text { of total } \\
\text { CP feed use }\end{array}$ \\
\hline crops & 326.6 & 51.7 & 35.6 & 16.1 & 342.7 & 180.7 & & 18.89 & 23.09 \\
\hline cereals & 290.2 & 31 & 34.2 & -3.2 & 287 & 175.9 & $10.1 \%$ & 17.77 & \\
\hline oilseeds & 32.8 & 19.8 & 0.8 & 19 & 51.8 & 1.6 & $20.0 \%$ & 0.32 & \\
\hline pulses & 3.6 & 0.9 & 0.6 & 0.3 & 3.9 & 3.2 & $25.0 \%$ & 0.80 & \\
\hline co-products (oilmeals) & 30.4 & 24.6 & 1.2 & 23.4 & 53.8 & 53.7 & & 21.08 & 25.78 \\
\hline soybean meal & 11.6 & 18 & 0.3 & 17.7 & 29.3 & 29.1 & $44.5 \%$ & 12.95 & \\
\hline rapeseed meal & 13.3 & 0.5 & 0.4 & 0.1 & 13.4 & 13.4 & $33.0 \%$ & 4.42 & \\
\hline sunflower meal & 4.9 & 3.5 & 0.4 & 3.1 & 8 & 8 & $36.0 \%$ & 2.88 & \\
\hline other meals & 0.6 & 2.6 & 0.1 & 2.5 & 3.1 & 3.2 & $26.0 \%$ & 0.83 & \\
\hline co-products (others) & 34.3 & 5.4 & 1.1 & 4.3 & 38.7 & 34.5 & & 4.73 & 5.78 \\
\hline starch industry & 5.1 & 0.8 & 0.4 & 0.4 & 5.5 & 4.7 & $19.0 \%$ & 0.89 & \\
\hline distillers dried grains & 3.6 & 1.1 & 0.2 & 0.9 & 4.5 & 4.5 & $28.0 \%$ & 1.26 & \\
\hline wet distiller grains & 6.8 & 0 & 0 & 0 & 6.8 & 6.8 & $6.4 \%$ & 0.44 & \\
\hline wheat bran & 8.4 & 0.1 & 0.2 & -0.1 & 8.3 & 8.3 & $15.5 \%$ & 1.29 & \\
\hline citrus pulp & 0 & 0.3 & 0 & 0.3 & 0.3 & 0.3 & $7.5 \%$ & 0.02 & \\
\hline beet pulp & 6.9 & 1.3 & 0.2 & 1.1 & 8.1 & 8.1 & $7.9 \%$ & 0.64 & \\
\hline molasses & 3.5 & 1.8 & 0.1 & 1.7 & 5.2 & 1.8 & $10.7 \%$ & 0.19 & \\
\hline by-products & 7.9 & 0.5 & 3 & -2.5 & 5.5 & 8.4 & & 2.24 & 2.74 \\
\hline fish meal & 0.5 & 0.3 & 0.1 & 0.2 & 0.8 & 0.6 & $66.0 \%$ & 0.40 & \\
\hline whey powder & 1.8 & 0.1 & 0.7 & -0.6 & 1.2 & 0.6 & $12.5 \%$ & 0.08 & \\
\hline SMP & 1.8 & 0 & 0.9 & -0.9 & 0.9 & 0.1 & $34.9 \%$ & 0.03 & \\
\hline processed animal protein & 3.8 & 0.1 & 1.3 & -1.2 & 2.6 & 2.1 & $60.0 \%$ & 1.26 & \\
\hline former foodstuff & & & & & & 5 & $9.5 \%$ & 0.48 & \\
\hline rhoughage & 1224.3 & 0 & 1.8 & -1.8 & 1222.5 & 1232.5 & & 34.85 & 42.61 \\
\hline grass & 942 & 0 & 0 & 0 & 942 & 942 & $2.5 \%$ & 23.55 & \\
\hline silage mais & 227 & 0 & 0 & 0 & 227 & 227 & $2.9 \%$ & 6.58 & \\
\hline fodder legumes & 52 & 0 & 0 & 0 & 52 & 62 & $7.2 \%$ & 4.46 & \\
\hline \multirow[t]{2}{*}{ dried fodder } & 3.3 & 0 & 1.8 & -1.8 & 1.5 & 1.5 & $17.0 \%$ & 0.26 & \\
\hline & & & & & & & & 81.79 & 100.00 \\
\hline
\end{tabular}

Bron: Europese Commissie (EC, 2020b). 


\section{Bijlage 2 Eiwitbalans Nederland}

Tabel B2.1 Eiwitbalans voor Nederland (2017/2018)

\begin{tabular}{|c|c|c|c|c|c|c|c|c|c|}
\hline $\begin{array}{l}\text { Crop/product } \\
\text { (million tons) }\end{array}$ & production & imports & exports & $\begin{array}{l}\text { net } \\
\text { imports }\end{array}$ & $\begin{array}{r}\text { total } \\
\text { mestic } \\
\text { use }\end{array}$ & ed use & $\begin{array}{l}\text { protein } \\
\text { content } \\
\text { (feed } \\
\text { use) }\end{array}$ & 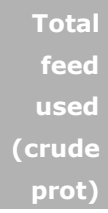 & $\begin{array}{r}\% \text { of } \\
\text { total CP } \\
\text { feed use }\end{array}$ \\
\hline crops & 1.34 & 21.23 & 3.87 & 17.36 & 18.70 & 9.83 & & 1.05 & 17.83 \\
\hline cereals & 1.34 & 14.49 & 1.65 & 12.85 & 14.18 & 9.32 & $10.1 \%$ & 0.94 & \\
\hline oilseeds & 0.01 & 6.46 & 2.13 & 4.33 & 4.33 & 0.34 & $20.0 \%$ & 0.07 & \\
\hline pulses & 0.00 & 0.27 & 0.09 & 0.18 & 0.18 & 0.17 & $25.0 \%$ & 0.04 & \\
\hline co-products (oilmeals) & 3.80 & 5.16 & 4.04 & 1.12 & 4.92 & 4.59 & & 1.72 & 29.14 \\
\hline soybean meal & 3.11 & 2.14 & 2.96 & -0.82 & 2.28 & 2.28 & $44.5 \%$ & 1.02 & \\
\hline rapeseed meal & 0.36 & 0.88 & 0.23 & 0.65 & 1.00 & 0.73 & $33.0 \%$ & 0.24 & \\
\hline sunflower meal & 0.34 & 0.65 & 0.39 & 0.26 & 0.60 & 0.54 & $36.0 \%$ & 0.19 & \\
\hline other meals & 0.00 & 1.50 & 0.46 & 1.04 & 1.04 & 1.04 & $26.0 \%$ & 0.27 & \\
\hline co-products (others) & 3.37 & 1.54 & 0.66 & 0.89 & 4.26 & 4.06 & & 0.64 & 10.84 \\
\hline starch industry & 0.89 & 0.25 & 0.14 & 0.11 & 0.99 & 0.85 & $19.0 \%$ & 0.16 & \\
\hline distillers dried grains & 0.66 & 0.33 & 0.00 & 0.33 & 0.99 & 0.99 & $28.0 \%$ & 0.28 & \\
\hline wet distiller grains & 0.69 & 0.00 & 0.00 & 0.00 & 0.69 & 0.69 & $6.4 \%$ & 0.04 & \\
\hline wheat bran & 0.21 & 0.48 & 0.23 & 0.25 & 0.46 & 0.46 & $15.5 \%$ & 0.07 & \\
\hline citrus pulp & 0.00 & 0.00 & 0.00 & 0.00 & 0.00 & 0.00 & $7.5 \%$ & 0.00 & \\
\hline beet pulp & 0.93 & 0.25 & 0.12 & 0.12 & 1.05 & 1.05 & $7.9 \%$ & 0.08 & \\
\hline molasses & 0.00 & 0.24 & 0.16 & 0.08 & 0.08 & 0.03 & $10.7 \%$ & 0.00 & \\
\hline by-products & 2.04 & 1.66 & 0.60 & 1.05 & 3.88 & 2.51 & & 0.37 & 6.29 \\
\hline fish meal & 0.00 & 0.01 & 0.00 & 0.01 & 0.80 & 0.01 & $66.0 \%$ & 0.00 & \\
\hline whey powder & 0.65 & 0.44 & 0.17 & 0.27 & 0.92 & 0.46 & $12.5 \%$ & 0.06 & \\
\hline SMP & 0.00 & 0.17 & 0.09 & 0.08 & 0.08 & 0.01 & $34.9 \%$ & 0.00 & \\
\hline processed animal protein & 0.00 & 0.46 & 0.21 & 0.25 & 0.25 & 0.20 & $60.0 \%$ & 0.12 & \\
\hline vegetable by-products & 1.39 & 0.57 & 0.14 & 0.43 & 1.82 & 1.82 & $10.0 \%$ & 0.18 & \\
\hline former foodstuff & & & & & & & $9.5 \%$ & 0.00 & \\
\hline roughage & 73.43 & 0.45 & 0.12 & 0.32 & 22.28 & 73.75 & & 2.12 & 35.90 \\
\hline grass & 65.30 & 0.45 & 0.12 & 0.32 & 65.62 & 65.62 & $2.9 \%$ & 1.87 & \\
\hline silage mais & 7.84 & 0.00 & 0.00 & 0.00 & 7.84 & 7.84 & $2.9 \%$ & 0.23 & \\
\hline fodder legumes & 0.28 & 0.00 & 0.00 & 0.00 & 0.28 & 0.28 & $7.2 \%$ & 0.02 & \\
\hline \multirow[t]{2}{*}{ dried fodder } & 0.00 & 0.00 & 0.00 & 0.00 & 0.00 & 0.00 & $17.0 \%$ & 0.00 & \\
\hline & & & & & & & & 5.90 & 100.00 \\
\hline
\end{tabular}

Deze tabel volgt het format van de EU-eiwitbalans (tabel B1.1) en is samengesteld op basis van diverse bronnen waaronder Eurostat, CBS, IDH (2020), informatie vanuit NEVEDI en expert informatie.

Bron: Wageningen Economic Research. 
Wageningen Economic Research Postbus 29703

2502 LS Den Haag

T 0703358330

Ecommunications.ssg@wur.nl

www.wur.nl/economic-research

Wageningen Economic Research RAPPORT

2021-023
De missie van Wageningen University \& Research is 'To explore the potential of nature to improve the quality of life'. Binnen Wageningen University \& Research bundelen Wageningen University en gespecialiseerde onderzoeksinstituten van Stichting Wageningen Research hun krachten om bij te dragen aan de oplossing van belangrijke vragen in het domein van gezonde voeding en leefomgeving. Met ongeveer 30 vestigingen, 6.500 medewerkers ( $5.500 \mathrm{fte}$ ) en 12.500 studenten behoort Wageningen University \& Research wereldwijd tot de aansprekende kennisinstellingen binnen haar domein. De integrale benadering van de vraagstukken en de samenwerking tussen verschillende disciplines vormen het hart van de unieke Wageningen aanpak. 



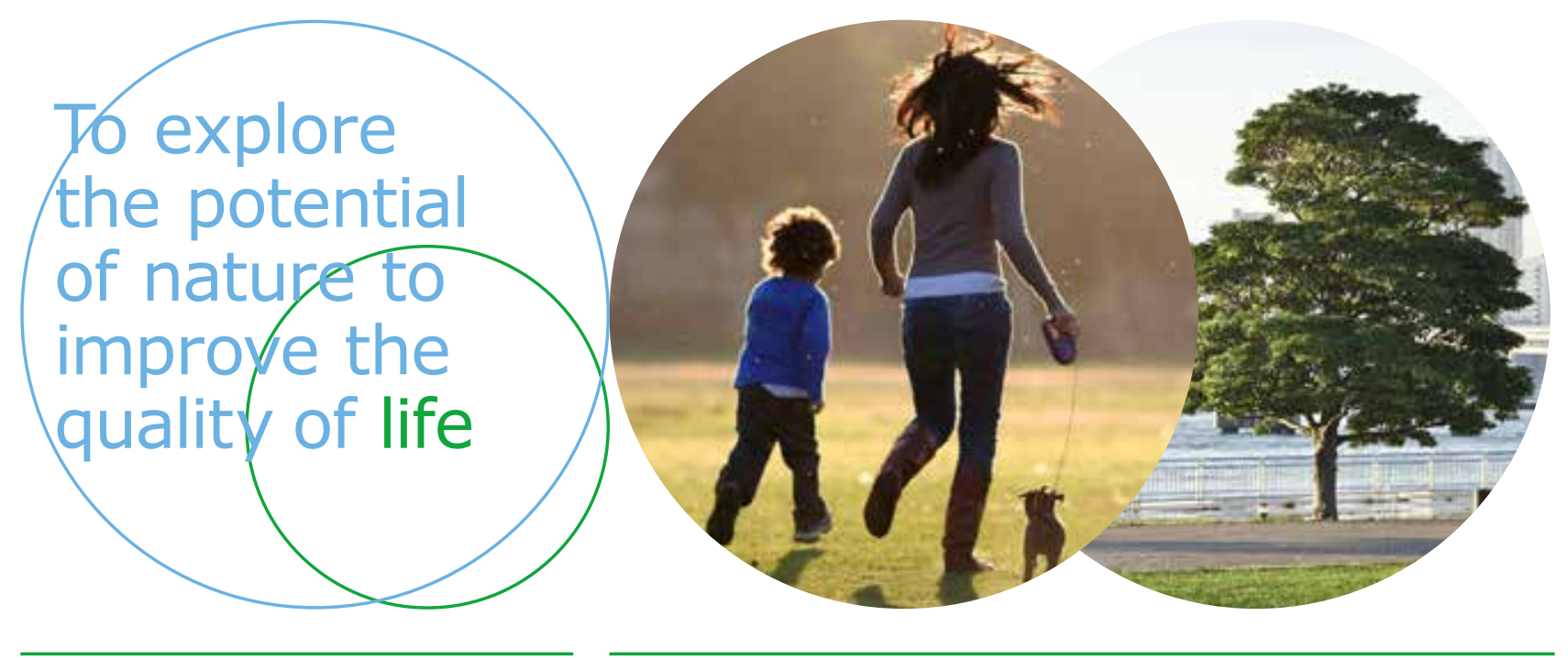

Wageningen Economic Research Postbus 29703

2502 LS Den Haag

T 0703358330

E communications.ssg@wur.nl www.wur.nl/economic-research

Rapport 2021-023

ISBN 978-94-6395-774-8
De missie van Wageningen University \& Research is 'To explore the potential of nature to improve the quality of life'. Binnen Wageningen University \& Research bundelen Wageningen University en gespecialiseerde onderzoeksinstituten van Stichting Wageningen Research hun krachten om bij te dragen aan de oplossing van belangrijke vragen in het domein van gezonde voeding en leefomgeving. Met ongeveer 30 vestigingen, 6.500 medewerkers ( $5.500 \mathrm{fte}$ ) en 12.500 studenten behoort Wageningen University \& Research wereldwijd tot de aansprekende kennisinstellingen binnen haar domein. De integrale benadering van de vraagstukken en de samenwerking tussen verschillende disciplines vormen het hart van de unieke Wageningen aanpak. 